I Consejo Nacional de Investigaciones Científicas y Técnicas (CONICET), Universidad de Buenos Aires (UBA), Instituto de Investigaciones Gino Germani (IIGG), Buenos Aires, Argentina spignuoli@conicet.gov.ar https://orcid.org.0000-0002-9918-093I

I I Universidade Federal do Rio de Janeiro (UFRJ), Departamento de Sociologia e Programa de Pós-Graduação em Sociologia e Antropologia, Rio de Janeiro, RJ, Brasil antoniobrasiljr@gmail.com https://orcid.org/oooo-oooI-8653-668X

\author{
Sergio Pignuoli Ocampo' \\ Antonio Brasil Jr."
}

\title{
O CENÁRIO “PÓS-LUHMANNIANO" E A AMÉRICA LATINA: ENTREVISTAS COM MARCELO NEVES E ALDO MASCAREÑO
}

Este número de Sociologia \& Antropologia traz um conjunto de textos dedicados à discussão sistemática do legado teórico do sociólogo alemão Niklas Luhmann, elaborados na América Latina. Vale, porém, a provocação: o que significa essa reflexão em um cenário claramente "pós-luhmanniano", como o nosso mundo contemporâneo?

Para nos ajudar a responder a essa questão, entrevistamos por e-mail Marcelo Neves, professor da Faculdade de Direito na Universidade de Brasília, e Aldo Mascareño, pesquisador sênior do Centro de Estudios Públicos em Santiago do Chile. Passamos aos dois um roteiro comum de perguntas, incluindo desde temas ligados a suas trajetórias até os desafios atuais de pensar os aportes da teoria dos sistemas sociais no contexto latino-americano. Os dois autores refletiram extensamente sobre as principais contribuições de Luhmann e de suas próprias obras - que, aliás, foram fundamentais para a aclimatação do programa sistêmico na região - para o enfrentamento dos fenômenos que desafiam a imaginação sociológica no presente.

Antes de seguirmos para as entrevistas, gostaríamos de abordar brevemente o que entendemos por cenário "pós-luhmanniano" e por que o padrão de recepção dos textos de Luhmann na América Latina pode contribuir decisivamente em uma agenda de pesquisa que atualize o legado de Luhmann em sentido criativo e sensível às transformações sociais em curso.

Cumpre ressaltar que o qualificativo "pós-luhmanniano" servia para indicar, tempos atrás, pesquisadores ou linhas de pesquisa interessados nos tra- 
balhos de Luhmann, mas que guardavam em relação à sua obra certa distância crítica. Portanto, pós-luhmanniano sugeria então uma fuga do programa de pesquisa elaborado pelo renomado sociólogo de Bielefeld. Nesse sentido, o prefixo pós- adotava o significado do prefixo ex-, uma vez que introduzia uma quebra de relações - e uma saída não muito bem resolvida - com o programa de investigação, por assim dizer, original, e não uma relação de simples posterioridade ou de sucessão descomplexada. Aqui, interessa-nos recuperar a etimologia do prefixo pós- e fazer valer literalmente o adjetivo pós-luhmanniano não para identificar necessariamente um grupo de pesquisadores, e sim para descrever o cenário contemporâneo.

O tempo mostra uma passagem evidente: transcorreram mais de 35 anos desde a publicação de Soziale Systeme e mais de 20 anos desde a aparição de Die Gesellschaft der Gesellschaft, sem falar nos demais livros e artigos deixados por Luhmann. Um simples passar de olhos nas agendas científica e política bastaria para assumir que o mundo social mudou consideravelmente desde então. Para não ir mais longe, fenômenos como a comunicação digital, a mudança climática global e de origem antrópica e as extremas desigualdade e exclusão sociais revelam que as afirmações do autor sobre a comunicação entre máquinas interconectadas, os riscos ecológicos e os limites da reinclusão social nas condições da diferenciação funcional sem dúvidas são precursoras, mas resultam insuficientes para a pesquisa. Até porque o volume da pesquisa sociológica nesses campos não para de crescer - e seria um erro ignorá-las. Essa questão se agrava ainda mais quando notamos que teríamos que revirar os textos do autor para encontrar pistas sobre os demais fenômenos que desafiam a imaginação sociológica no presente, como os novos extremismos, a irrupção da nova onda dos movimentos raciais e de gênero, as novas formas de guerra entre potências globais completamente teledirigidas, a chamada pós-verdade etc. Por fim, a questão da atualidade se torna decisiva quando nos damos conta de que a ciência não é mais a mesma: a cibernética de segunda ordem, a biologia da autopoiese, o construtivismo do observador podem ter-se tornado anacrônicos em face das neurociências, da nanotecnologia dos materiais orgânicos e inorgânicos, do avanço da interdisciplinaridade - como no caso das chamadas data science e da network theory, com inegáveis consequências para a própria sociologia - e da possibilidade de uma "interdisciplina sem disciplina".

Já no campo específico da pesquisa social e da sociologia, a sensação é de que permanece pouco daquilo que Luhmann magistralmente interpelou. A urgência da teoria se transformou em instrumentalismo conceitual e na busca de caixas de ferramentas dóceis e autorizadas; o trabalho de campo reserva cada vez menos espaço para o empírico, priorizando a tecnificação quali- ou quantitativa dos dados; o problema da representatividade e da validade chegou a planos antes insuspeitáveis devido à aparição de novos métodos de pesquisa digital (questionários online, simulações multiagente, análise de sentimentos 
em mídias sociais, processamento de grande volume de dados não parametrizados ou data mining). Em resumo: nem o mundo, nem a ciência, nem a sociologia são os mesmos que Luhmann interpelou. Por isso falamos de um cenário pós-luhmanniano.

Para deixar mais claro: o cenário pós-luhmanniano não é um lugar em que o programa de Niklas Luhmann careça de vigência. O ponto é mais simples, mas ainda mais nevrálgico que isso: trata-se apenas de partir do fato de que o legado de Luhmann já não supõe o contexto histórico, científico e disciplinar de Luhmann. De modo que a magnífica heurística positiva disponível em seus trabalhos - associada aos extraordinários avanços que realizou o autor no campo da teoria geral dos sistemas, teoria dos sistemas sociais, teoria da sociedade, sociologia das organizações, teoria da modernidade e da sociedade mundial, por exemplo - já não pode ser assumida ou aplicada sem mais. Dirk Baecker já alertou sobre esse problema no âmbito da teoria da sociedade e assinalou que, frente à complexidade da sociedade futura, é possível que a complexidade da Systemtheorie não seja suficiente. Do mesmo modo, Rudolf Stichweh, Alfons Bora e Urs Stäheli, entre outros, identificaram diferentes necessidades de correção e/ou complementação dos argumentos originais de Luhmann. Os diagnósticos convergem para um mesmo ponto: legado e vigência já não correspondem a esse cenário, colocando o legado de Luhmann em um horizonte problemático, pois seu tratamento não pode ser apenas positivo, mas antes forçosamente reflexivo, centrado em indagações críticas e em novos desenvolvimentos.

Essa situação não impõe necessariamente uma atitude defensiva ou a passagem direta a uma heurística negativa: também é possível observar o cenário como uma oportunidade para expandir o programa. Na recepção de Luhmann - pelo menos no campo mais organizado da teoria sociológica -, há duas grandes tradições: uma reducionista ou "crítica" e outra celebratória ou "luhmanniana”. A primeira procurou reduzir a proposta de Luhmann a posições amplamente questionadas na pesquisa social. Nessa vasta bibliografia, observam-se diversas tentativas de reduzir o programa de Luhmann ao funcionalismo, ao coletivismo, à macrossociologia, ao biologicismo, ao positivismo, ao eurocentrismo e/ou ao conservadorismo político. Essa recepção malogra seu objetivo posto que omite as duras críticas dirigidas pelo sociólogo de Bielefeld em relação a essas posições, segmentando as referências textuais de Luhmann de maneira bastante questionável e/ou interessada de acordo com seus objetivos. Por não justificar essas problemáticas reduções, essa tradição oscila entre diversas formas de reducionismo. A oportunidade de expandir o programa requer esforços críticos muito mais elaborados que os oferecidos até o momento por uma tradição que simplesmente menospreza o legado de Luhmann incorrendo em falácias interpretativas. Em oposição à tradição crítica, a tradição celebratória ou luhmanniana goza de considerável superioridade. A simples 
vocação de tomar ao pé da letra os textos de Luhmann é suficiente para mostrar os reducionismos imperantes nas "críticas" e para assumir positivamente a investigação social, incluída a aplicação da sociologia luhmanniana em trabalhos empíricos.

De todo modo, chama a atenção a perseverante vigência da tradição crítica, a despeito das fortes réplicas feitas pela tradição luhmanniana. Sem desconsiderar seu afinco, a última não conseguiu, nem remotamente, dissolver a primeira, que goza de excelente saúde nos dias que correm. Essa situação, que vem de longa data, foi assumida pela recepção luhmanniana nos termos de uma luta da "ilustração sistêmica" contra o "obscurantismo" da recepção mais disseminada, sendo então o problema predominante nela a correta compreensão do autor. Essa narrativa fortalece a heurística negativa do programa: “Luhmann não é isto, Luhmann não é aquilo...". O preço, entretanto, é muito alto, pois se retira mobilidade à heurística positiva. Responde-se rapidamente às críticas, mas o mesmo não ocorre com os novos problemas que oferece o mundo social. Trata-se de um programa de pesquisa robusto e monolítico, imune às "críticas" e que combate o "obscurantismo"; ele reage lentamente à dinâmica do entorno e levanta suspeitas a quaisquer questionamentos à teoria dos sistemas, sendo então resistente à renovação de seu fundamento operativo.

Dentro do novo cenário pós-luhmanniano, uma eventual - e utópica vitória final da "ilustração" será insuficiente ou, ainda pior, irrelevante. Os desafios trazem consigo os novos problemas e exigem a demonstração da vigência do legado frente a eles - e isso não será proporcionado nem sequer pelo esforço mais exegético que conseguisse demonstrar o que disse Luhmann em cada detalhe de seu valioso legado. Os novos desafios colocam essa tradição em uma situação incômoda e inédita até agora: indicar o que pode oferecer a pesquisa em sistemas aos novos focos de atenção e aos problemas a eles associados. Sintomático e agravante do quadro é o fato de que a "ilustração sistêmica" chega tarde à discussão sobre a vigência do legado. Faz mais de uma década que o emergente sistemismo realista crítico, com novos autores como Dave Elder-Vass, Poe Yu-ze Wan e John Mingers, propõe literalmente que "The future success of social systems theory depends on being able to move beyond Luhmann" (Elder-Vass, 2007: 409). É certo que esse novo programa carrega certo lastro ainda da tradição reducionista - que, em muitos ou quase todos os sentidos, empobrece o debate sistêmico - e que as réplicas luhmannianas que recebeu têm sido incisivas - como dito, a heurística negativa tonificada até a hipertrofia permite à Systemtheorie replicar assim. Há, contudo, um ponto que passou despercebido: a disputa não é pelo legado, e sim pela vigência - e o troféu é o futuro, ou seja, o tempo. Para além de seu evidente desacerto interpretativo, o novo sistemismo realista propõe à Systemtheorie uma disputa de novo tipo. Os contendores não são mais nem "ilustrados" nem "críticos", e a disputa não é pelo legado, mas por recursos e tempo. A Systemtheorie possui 
recursos que permitam sustentar sua vigência como programa de investigação no tempo? Ela os possui no presente? Ou os terá no futuro? Onde estão? No legado de Luhmann e em sua exegese? A pergunta sobre a vigência presente e futura desloca a luta em torno da ilustração sistêmica e expõe a razão pela qual a tradição luhmanniana, tal qual a tradição reducionista, perde também a oportunidade de problematizar a relação entre o legado e a vigência que oferece o cenário pós-luhmanniano.

O sistemismo realista e os programas que virão no futuro não se interessam em desmontar "criticamente" a obra de Luhmann. Sua disputa é pelo futuro e, em face dessa questão, as réplicas "ilustradas" serão insuficientes e até mesmo desacertadas. Ainda que refinemos a interpretação do conceito de comunicação entre máquinas interconectadas, não esgotaremos a análise das formas de comunicação digital; por mais que busquemos nos textos maiores ou menores de Luhmann, a neurociência arrasa a concepção de sistema nervoso do autor e mostra os vários problemas programáticos de sua aposta interdisciplinar, bem como fenômenos tais quais a financeirização dos não pagamentos - dotando-os de capacidade de enlace -, a descentralização das decisões jurídicas, a aparição dos problemas de veracidade na codificação da informação gerada pelos mass media, a valorização da prosperidade como continuum entre imanência e transcendência religiosas etc. Nesse estado de coisas, se a resposta aos novos desafios recorresse à necessidade de uma melhor interpretação, a tradição luhmanniana cairia em um erro histórico, a saber, apostar na conversão do legado de Luhmann em um clássico das ciências sociais. Quer dizer, os luhmannianos seriam aqueles que assumiriam que a teoria já está pronta e que se trata só de refinar sua intepretação - e, caso necessário, bastaria anexar outros territórios para ampliar o reino etc. (Luhmann I983, I984, I986). Isso acabaria segmentando o programa, limitando sua problemática e fazendo com que a heurística negativa primasse sobre a positiva. Converteria, ainda, em dogmatismo a ortodoxia e a custódia do legado de Luhmann, imobilizando-o talvez em poucas décadas. Em outras palavras, a hipóstase da Systemtheorie em uma prima philosophia da pesquisa social não consolidará nenhum novo paradigma, e sim erigirá - em caso irônico de equivocada práxis sistêmica - Luhmann em um obstáculo epistemológico dentro do cenário pós-luhmanniano. É inegável que uma interpretação densa será muito mais proveitosa que uma interpretação falaciosa do legado, mas o que é decisivo aqui é que a interpretação da palavra já não basta para sustentar a vigência do legado luhmanniano num cenário pós-luhmanniano.

Um aspecto singular do novo cenário está na melhor posição relativa e nas vantagens comparativas que nele assume a recepção latino-americana. Há décadas os(as) pesquisadores(as) da região interessados(as) em dialogar com a obra de Luhmann operam em chave de crítica e reformulação. Desde Miguel Chávez, Marcelo Neves, Darío Rodríguez, Fernando Robles e Marcelo Arnold, dis- 
cípulos e colaboradores de Luhmann em Bielefeld, ou ainda tradutores notáveis como Javier Torres Nafarrate, até os jovens alunos e professores dos nossos cursos atuais na universidade, passando por nomes como Aldo Mascareño, Jorge Galindo, Marco Ornelas, Ignacio Farias, entre muitos outros - em todos eles a pergunta central é: qual a vigência da Systemtheorie para a América Latina? Que tipos de crítica e de reelaborações devem ser feitos aos argumentos originais diante de problemas e situações estranhas a eles? Nesse sentido, as tarefas que o cenário pós-luhmanniano generalizou e tornou incontornáveis são parte do trabalho habitual dos pesquisadores sistêmicos latino-americanos, ou, para dizê-lo com outras palavras, são constitutivas da recepção latino-americana, que não só está habituada a elas, mas também opera reflexivamente sua própria acumulação do conhecimento.

Isso não significa que não existam desafios consideráveis a enfrentar desde e a partir da América Latina para a disputa em torno da vigência do legado. Podemos ajudar a visibilizar alguns deles mediante breve exploração bibliométrica, que permite detectar, numa leitura a distância (nos termos de Franco Moretti, 20I3), alguns padrões e regularidades da recepção latino-americana. A despeito de suas limitações - as ferramentas e os dados disponíveis permitem apenas a análise da produção em artigos, deixando fora a volumosa quantidade de livros dedicados à teoria dos sistemas na região -, a pesquisa bibliométrica permite capturar certas dinâmicas da comunicação científica por meio de uma quantidade imensa de informações (Leydesdorff, 200I).

Um desses desafios - como sugere a imagem abaixo, elaborada a partir dos dados dos I.I 26 artigos que citam (pelo menos uma vez) algum texto de Niklas Luhmann na base SciELO de revistas científicas entre 2002 e 2019 (até outubro) - é a necessidade de maior integração entre os(as) pesquisadores(as) da região. ${ }^{I}$ Se a distribuição dos artigos dos cinco países da coleção SciELO que mais citam Luhmann (Brasil, Chile, Colômbia, México e Argentina) pelas 20 principais palavras-chave é relativamente equilibrada, embora não exatamente simétrica - o que mostra amplo potencial de comunicação entre os países -, por outro lado, a publicação em revistas científicas parece muito segmentada por critérios de idioma. Os autores com afiliação em instituição brasileira publicam basicamente no Brasil e em português, e os autores localizados nos outros quatro países publicam preferencialmente em suas revistas locais, porém com maior integração (com a notável exceção dos autores na Argentina, que publicam basicamente fora de seu país no contexto das revistas indexadas na Base SciELO). A publicação científica em revistas é a que tem potencial para a circulação mais rápida, se comparada aos livros e às publicações de papers em congressos, até mesmo pela hegemonia do paradigma da "ciência aberta" na região. Acreditamos, portanto, que há muito o que avançar por aqui - e este número de S\&A procura justamente fortalecer os canais de comunicação "sistêmica" na América Latina. 


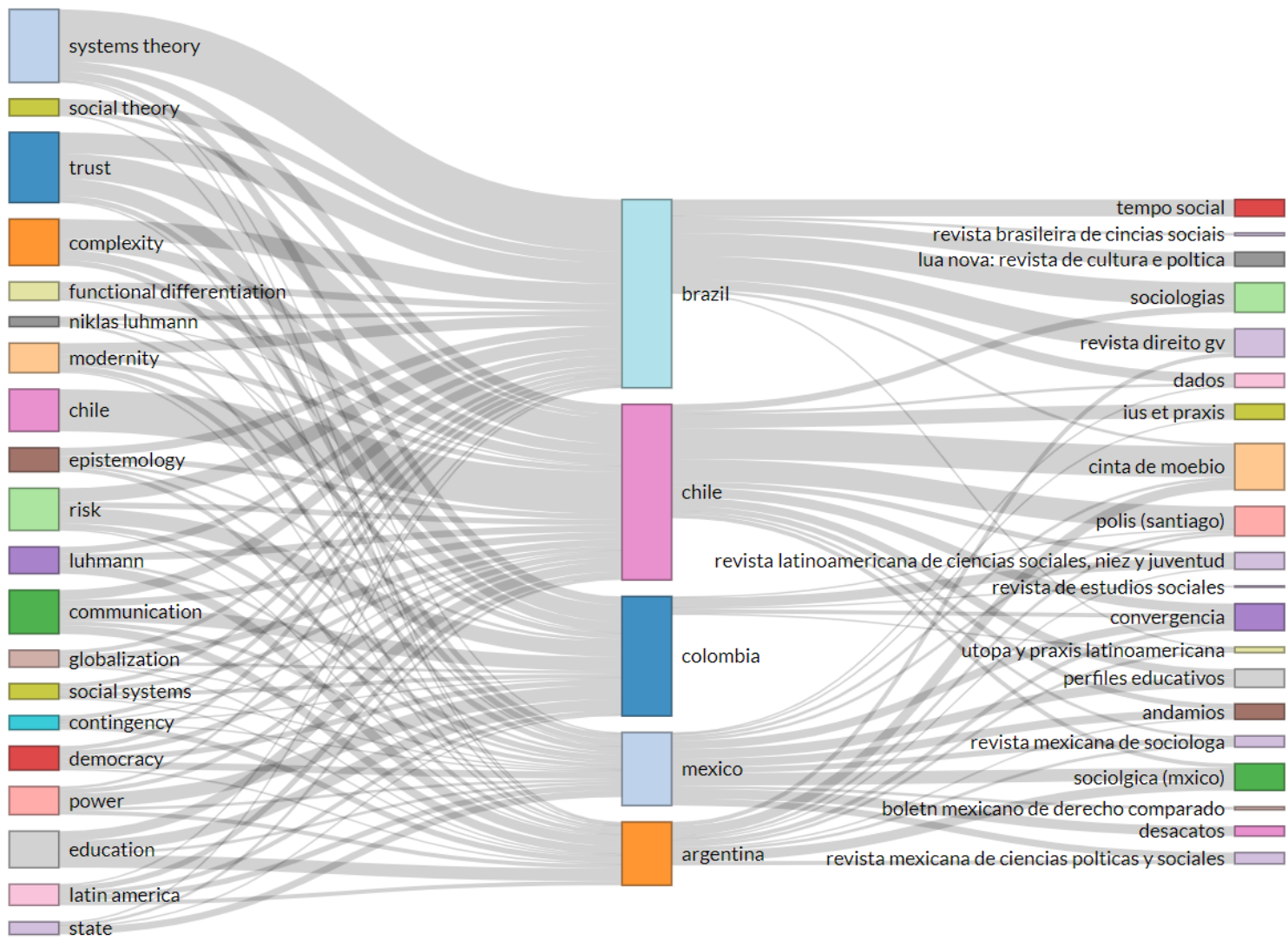

Figura I

Three fields plot: palavras-chave (20 mais frequentes), afiliação institucional por país (cinco com mais artigos) e revistas (20 com mais artigos)

Fonte: SciELO/WoS (2002-2019).

Visualização: Bibliometrix. 
Outro dado que chama a atenção para o padrão da recepção latino-americana - seu espírito heterodoxo e de revisão crítica do legado - diz respeito às relações mais importantes de cocitação no interior desse conjunto de I.I 26 artigos da coleção SciELO. Como era de esperar, o autor mais citado junto a Niklas Luhmann é Jürgen Habermas, seguido de (nesta ordem) Talcott Parsons, Humberto Maturana, Anthony Giddens, Pierre Bourdieu, Michel Foucault, Max Weber, Marcelo Neves, Aldo Mascareño e Ulrich Beck, para ficarmos nas dez cocitações de mais peso. Chama a atenção a relevância de Humberto Maturana - reconhecida pelo próprio Luhmann - mas igualmente a presença de Marcelo Neves e Aldo Mascareño, sinalizando justamente o lugar da recepção criativa latino-americana nesse conjunto de trabalhos, que vai acumulando reflexivamente um estoque de conhecimentos. Não por acaso, buscamos por meio das entrevistas que compõem este número de S\&A entender melhor o percurso formativo desses dois autores, vetores fundamentais para a aclimatação da teoria dos sistemas sociais na região.

Por outro lado, observando os dados de cocitação no nível das obras citadas (mínimo de cinco citações), encontramos um padrão de relação que sugere algumas partições. À esquerda, os dois grupos mais densos de obras citadas (em verde e em rosa), em sua maioria do próprio Luhmann, apontam para um intenso compartilhamento de referências sistêmicas, polarizado grosso modo no eixo vertical entre os temas da teoria social e da complexidade (acima) e a discussão do sistema jurídico (abaixo) - não por acaso, Sistemas sociais é o livro mais citado e o maior betweener entre esses dois grupos. Já à direita, surgem dois outros grupos de referências, um mais próximo e outro mais remoto. O grupo em laranja associa fortemente alguns textos de Luhmann, como Sociologia do risco, a referências centrais na discussão sobre risco e modernidade, como Urich Beck e Anthony Giddens. O grupo em azul, mais distante, conecta os trabalhos de Luhmann sobre confiança com a problemática das redes e do capital social (particularmente com os trabalhos de Granovetter, Putnam e Coleman). A topologia da rede de cocitações gerada indica forte densidade no compartilhamento das referências sistêmicas entre si e maior rarefação das ligações entre as obras fundamentais de Luhmann e aquelas ligadas aos temas da modernidade e risco e aos das redes sociais e confiança - provavelmente, esses dois campos na América Latina fazem um uso basicamente instrumental da teoria dos sistemas, hipótese que teria que ser investigada mais a fundo. Seja como for, o padrão de cocitação no nível das obras ilustra bem o desafio de "traduzir" melhor a capacidade de interpelação da obra de Luhmann para outros domínios da pesquisa social e, mais ainda, de mostrar sua produtividade para a exploração dos fenômenos empíricos. 


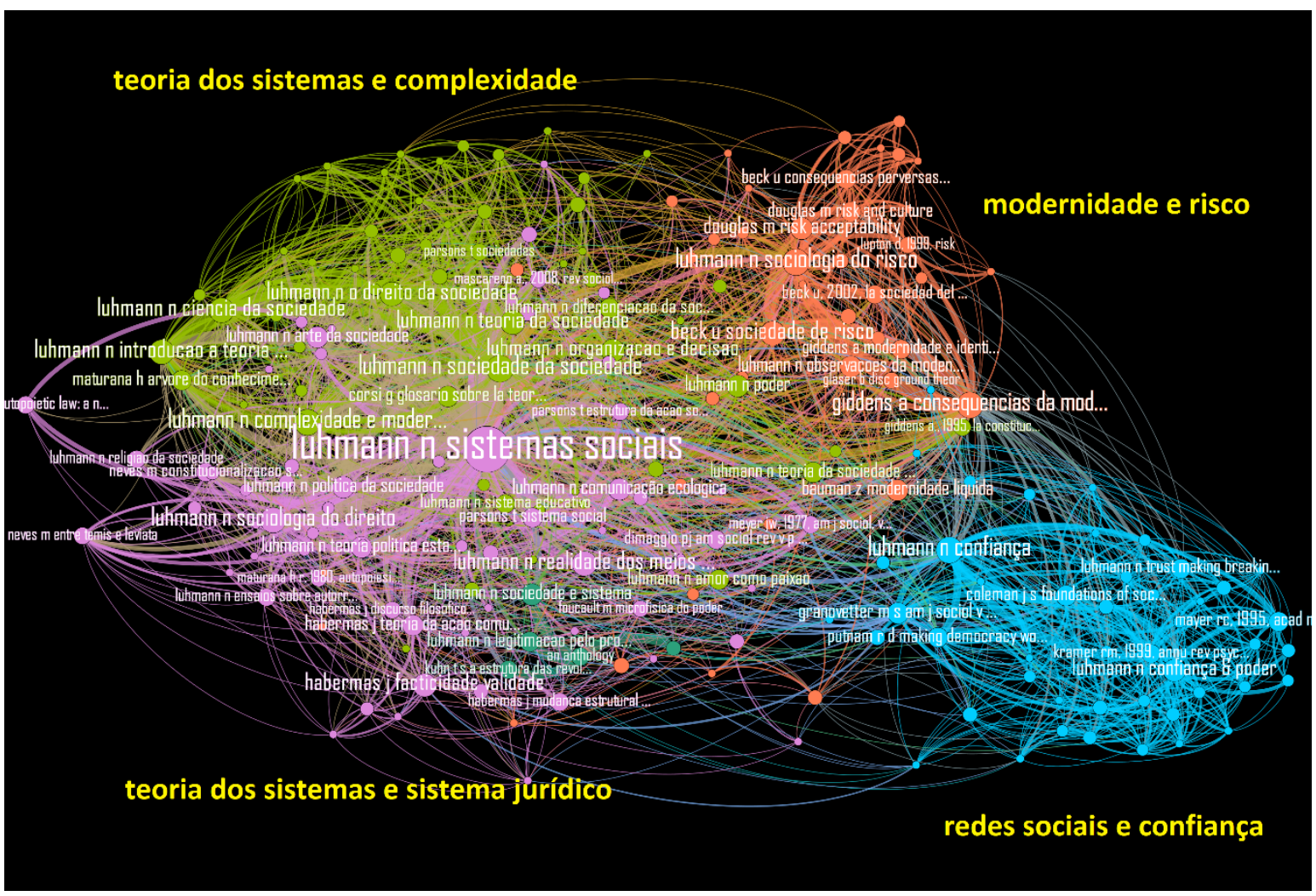

Figura 2

Rede de cocitação de referências

bibliográficas (frequência mínima=5x)

Fonte: SciELO/WoS (2002-2019).

Visualização: VOSViewer e Gephi.

Como já dito, o lugar e o sentido que a teoria dos sistemas ocupará no futuro dependem de uma série de operações e disputas cujo desenlace é totalmente contingente. Podemos dizer, no entanto, que o potencial de comunicação entre o repertório sistêmico e as ciências sociais na América Latina é bastante considerável não só pelo espírito "heterodoxo" que anima a nossa recepção, mas também pelo interesse crescente que sua obra vem despertando. Em levantamento ainda em curso sobre a coleção "Ciências Humanas" da SciELO/Brasil," Luhmann sempre esteve entre os I50 autores mais citados nas referências de um universo de quase $50 \mathrm{mil}$ artigos de diferentes áreas do conhecimento, no período que vai de 2002 a 2019 . E, mais significativo ainda, entre 2014 e 2016 as citações de Luhmann atingiram o pico de I55 citações, colocando-o como o 50응 autor mais mencionado (à frente de, por exemplo, Marcel Mauss). Se voltarmos aos I.I 26 artigos de toda a coleção SciELO que citam pelo menos uma vez algum texto de Luhmann, encontramos a seguinte curva temporal, que revela um crescimento bastante expressivo nos últimos anos: 
24

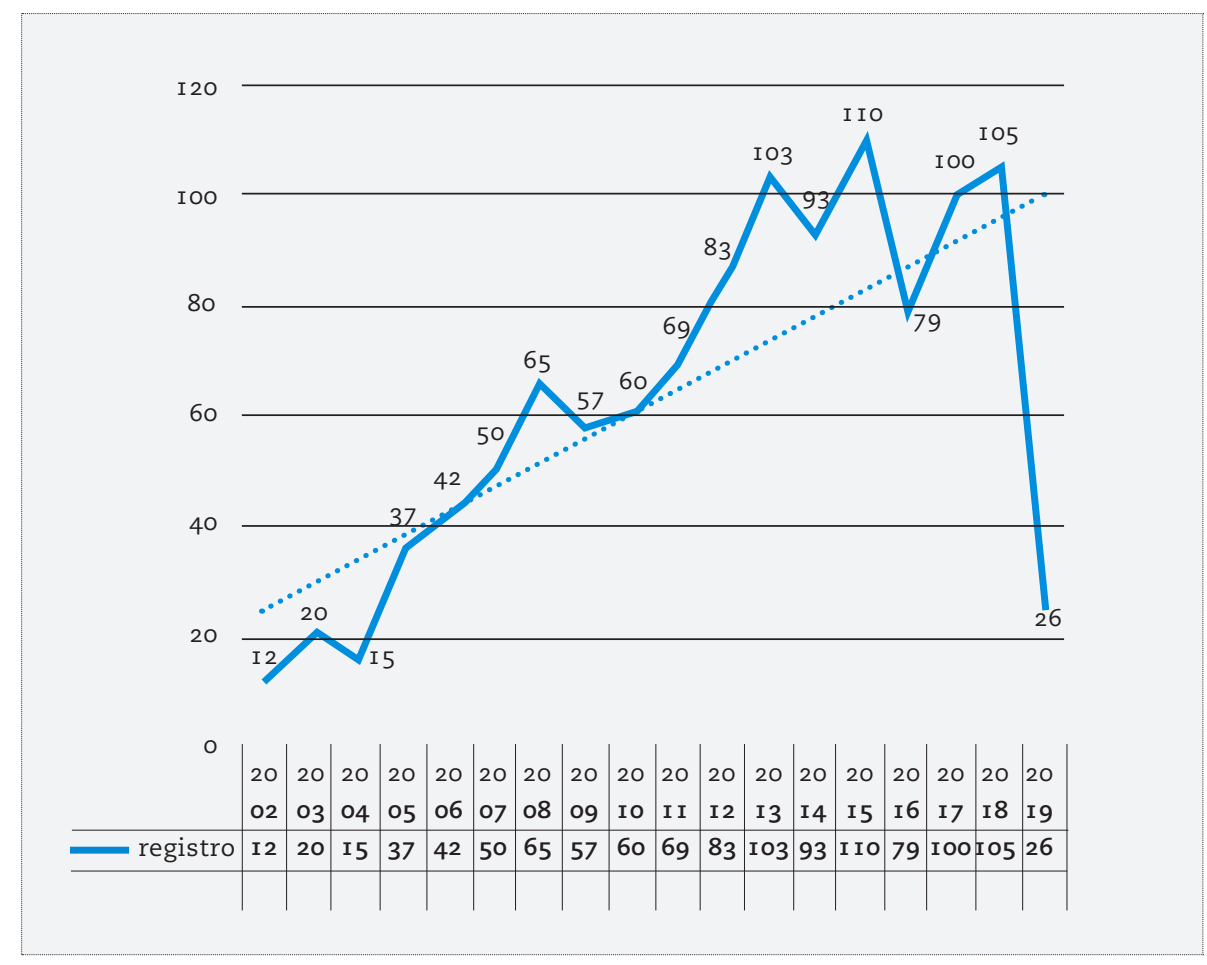

Figura 3

Evolução temporal dos I.I 26 artigos que citam Luhmann (pelo menos uma vez)

Fonte: SciELO/WoS (2002-2019).

Este número especial de S\&A procura, portanto, cumprir um duplo papel. De um lado, adensar as discussões em curso que exploram as potencialidades do legado de Luhmann no atual cenário pós-luhmanniano, ou seja, sua vigência, fincando-se naquilo que reputamos como o melhor de nossa recepção latino-americana - não dogmática e atenta aos fenômenos empíricos à primeira vista estranhos ao universo original de problemas da teoria dos sistemas sociais. As duas entrevistas aqui reunidas, feitas a partir de um roteiro básico similar com Marcelo Neves e Aldo Mascareño, iluminam de modo poderoso esse ponto. De outro lado, servir como vetor de maior integração da comunidade de especialistas na teoria dos sistemas na região, publicando quatro artigos que desafiam o senso comum dos não especialistas - que ainda a consideram uma teoria "ensimesmada", macrossociológica e avessa à pesquisa - e que expandem a agenda teórica e empírica da teoria. Hugo Cadenas e Aldo Mascareño trazem uma perspectiva histórico-evolucionária da diferenciação funcional no continente americano, mostrando a necessidade de descentrar a sociologia latino-americana tanto de sua visão do presente quanto do nacionalismo metodológico. Marco Estrada Saavedra interpela a literatura sobre movimentos sociais a partir de um conceito sistêmico do "político" e da introdução da distinção a política/o político a fim de "desestatizar" nossa concepção do fenômeno, abrindo-o a novos horizontes. João Paulo Bachur nos ofe- 
rece uma autorreflexão crítica desde dentro da teoria dos sistemas, examinando programaticamente como a forma inclusão/exclusão pode ser incorporada a uma teoria do conflito orientada para questões distributivas. Por fim, Juan Pablo Gonnet discute, a partir de Luhmann, a possibilidade de se superar uma visão disjuntiva das ordens interacional (microssociológica) e da sociedade (macrossociológica), brindando-nos com uma perspectiva metodológica para a integração do conhecimento sociológico. Como podemos ver, os artigos, ao conectar a teoria dos sistemas - na perspectiva da América Latina - aos problemas mais caros da teoria sociológica, terão a chance de sensibilizar os pesquisadores das ciências sociais que, até aqui, permaneceram indiferentes às potencialidades do programa sistêmico.

\section{ENTREVISTA COM MARCELO NEVES}

\section{Sobre a trajetória acadêmica e a recepção da teoria dos sistemas sociais}

Sociologia \& Antropologia. Como tomou contato com a obra de Luhmann? Como observa a recepção da Teoria dos Sistemas Sociais (TdSS), ou da perspectiva dos sistemas sociais, na América Latina (AmLat)? Quais são, em sua opinião, os desenvolvimentos da TdSS mais inovadores na região, incluindo o seu próprio trabalho?

Marcelo Neves. Meu primeiro contato com a obra de Niklas Luhmann ocorreu por intermédio de meu professor de sociologia do direito, na Faculdade de Direito do Recife, da Universidade Federal de Pernambuco, Cláudio Souto, em I98I, quando eu cursava o mestrado em direito naquela instituição. No início da década de I980, Luhmann proferiu algumas palestras no Recife a convite de Cláudio Souto. Em uma dessas palestras, ele tratou da autopoiese dos sistemas sociais e foi questionado pelo meu orientador de mestrado, Lourival Vilanova, que era vinculado ao modelo de input/output da tradição sociológica americana dos anos I950 e i960. Foi um debate de alto nível em uma tarde iluminada lá no prédio do Centro de Filosofia e Ciências Humanas da UFPE, no auditório do Departamento de Sociologia. Eu fiquei impressionado, mas tinha certa restrição à aplicação irrestrita do modelo de autopoiese do direito nas condições históricas modernas coloniais ou neocoloniais dos países periféricos.

Cláudio Souto foi orientando de Luhmann no seu doutorado em sociologia na Universidade de Bielefeld, concluído em I982.3 Contudo, na busca de uma lei geral do social, Souto apresentou sua própria teoria sociológica, que apontava para a semelhança como orientação básica de um composto siv (sentimento, ideia e vontade) perante outro composto siv e, portanto, como catalisadora primária da vida social. Tornou-se amigo de Luhmann, porém não seguiu sua teoria dos sistemas sociais. 
É por isso que meu entendimento da recepção da obra de Luhmann no Brasil não decorreu dessa aproximação inicial intermediada por Cláudio Souto, mas sim de obras publicadas a partir da década de I980, disseminadas especialmente pela USP, sobretudo pelo espaço bacharelesco do Largo de São Francisco. Essa recepção inicial parecia-me problemática e com um quê de colonialismo cultural. Apenas se procurava repetir bem o que Luhmann dizia. Em um primeiro momento, ainda estudante, esse caráter controverso da recepção não me levou a uma crítica mais forte ou radical. Mas, posteriormente, minhas objeções a essa postura estimularam meu projeto de tese de doutorado, que se desenvolveu principalmente para apontar os limites da teoria luhmanniana nos contextos periféricos da sociedade mundial. Durante meu doutorado na Alemanha, entre I987 e I99ı, que concluí sob a orientação de Karl-Heinz Ladeur (Universidade de Bremen) e coorientação de Niklas Luhmann (Universidade de Bielefeld), foi-se tornando cada vez mais claro que aquela recepção inicial da teoria dos sistemas sociais de Niklas Luhmann, especialmente no que concerne ao direito, era superficial, colonizada e de um ecletismo ingênuo, típico da retórica bacharelesca. Por exemplo, juntava-se Luhmann com Hannah Arendt sem qualquer intermediação, como se tudo que viesse de celebridades acadêmicas pudesse ser compatível entre si.

Posteriormente, a partir da década de 2000, surgiu uma recepção da TdSS luhmanniana mais satisfatória na América Latina. As obras de Darío Rodríguez e Aldo Mascareño no Chile são exemplos relevantes de reflexão sobre o modelo de Luhmann, sem se reduzirem a uma mera repetição ou discussão exegética. No Brasil, apareceram trabalhos como o de Orlando Villas Bôas Filho, João Paulo Bachur, Maurício Palma e, sobretudo, de Pablo Holmes, ${ }^{4}$ que esboçam uma reflexão autônoma sobre a teoria luhmanniana. Em diálogo crítico com a teoria da evolução de Luhmann, cabe citar o brilhante trabalho de Fábio Portela. ${ }^{5}$ No entanto, no geral, sua recepção no Brasil permanece muito orientada por um modelo bacharelesco ou exegético, no qual as disputas retóricas sobre a semântica luhmanniana sobressaem, sem problematização e contextualização do debate no contexto brasileiro e latino-americano.

S\&A. Ao longo de sua destacada trajetória, que desafios, obstáculos e surpresas enfrentou por parte de colegas e estudantes? Notou alguma mudança ao longo do tempo? Em relação aos obstáculos, qual foi o mais difícil de enfrentar? Considera que alguns obstáculos foram facilmente superados e outros ainda não? No seu entender, quais são os desafios que enfrentará a perspectiva de sistemas sociais em um futuro próximo na região?

M.N. Minha trajetória acadêmica não foi linear. Além da minha estada de doutorado na Alemanha (I987-I99I), em um determinado momento, em I996, por exemplo, deixei o Brasil e permaneci na Alemanha e Europa em geral por cerca 
de sete anos, até 2003. Quando voltei, tive certa dificuldade de me reinserir na vida universitária e acadêmica.

Foi com os alunos que tive menos dificuldades. Algumas vezes, irritavame quando o aluno não admitia que certas ideias e conceitos foram desenvolvidos por mim. Uma aluna na Faculdade de Direito do Recife foi bem sincera, dizendo-me mais ou menos o seguinte: "Professor, eu pensei que os pares conceituais de subintegração/sobreintegração e subcidadania/sobrecidadania fossem de Luhmann, pois eu pensava que nós aqui não podíamos criar conceitos e teorias. Foi você mesmo quem desenvolveu esses conceitos? Nunca podia imaginar."

Tive, sim, problemas com alguns colegas, principalmente quando voltei do meu doutorado para o Brasil em I99 I e quando retornei ao Brasil em 2003 Havia uma incompreensão da minha obra e certas maledicências resultantes de uma mentalidade provinciana em certos espaços universitários. Com o tempo, também em virtude das traduções das obras tardias de Luhmann para o português, espanhol e inglês, esse estado de coisas foi-se modificando. Não dava mais para negar que Luhmann levou a sério minhas críticas, como se extrai de diversas obras dele posteriores ao meu doutorado. Aquela situação anterior esvaeceu-se e uma nova geração surgiu na década de 20I0, que passou a ter certa consideração por minha obra. Os que mantêm os comentários antigos de desprezo não são hoje mais levados a sério.

Mas, ainda em finais dos anos 2000, houve situações de deboche, como o motivo da rejeição de artigo de minha autoria por uma revista de ciências sociais brasileira (2008). Um parecerista disse que eu não entendia bem de Luhmnan nem de Habermas (com quem dialogava no meu texto), imputandome confusão sobre os conceitos desses autores (eu admitiria a rejeição por outro motivo). É interessante que, alguns anos antes (200I), eu fora convidado pelo Departamento de Ciências Sociais da Universidade Johann Wolfgang Goethe, em Frankfurt am Main, para ministrar, na qualidade de professor catedrático substituto [Vetretungsprofessor], cursos sobre a teoria dos sistemas sociais (Luhmann) e a teoria do discurso (Habermas). Lecionei sobre esses temas durante dois semestres naquela universidade, deparando-me então com um comentário brincalhão de Jürgen Habermas, já aposentado, em um jantar informal com a presença de Karl-Otto Apel e Hauke Brunkhorst: "você é o único que está dando um curso sobre minha teoria neste semestre na universidade. Precisa um brasileiro vir aqui para isso?" Também já havia sido convidado para publicar três verbetes sobre "mundo da vida", "evolução" e sobre o debate "Habermas/ Luhmann" no Habermas-Handbuch (em português, Manual Habermas). ${ }^{6}$ E já se destacavam com frequência citações de minha obra por Luhmann e Habermas, assim como por membros de seus círculos teóricos na Alemanha e outros países da Europa. ${ }^{7}$ Mas, enfim, o trabalho foi publicado em renomado periódico alemão. ${ }^{8}$ Suponho que sua rejeição pelo parecerista resultou de que o artigo 
não apenas repetia exegética e obedientemente esses autores, mas desenvolvia um diálogo crítico com eles.

Um deboche mais recente em relação a minha obra marca-se por desonestidade intelectual e irresponsabilidade acadêmica. Um sociólogo populista atribuiu a minha teoria e à de Luhmann um "racismo mal disfarçado de culturalismo", imputando-me uma teoria afirmativa de uma "singularidade" da "sociedade brasileira". Mas, como esclareci a esse respeito no posfácio à edição brasileira de minha tese de doutorado, ${ }^{9}$ a teoria dos sistemas sociais parte de um conceito de sociedade mundial (portanto, algo como "sociedade brasileira" não existe) e trata de seus problemas estruturais, consistindo, de certa maneira, em um modelo anticulturalista e radicalmente contrário à vinculação do conceito de sociedade a uma determinada singularidade cultural. E há algo de disparatado nesse sociólogo populista. Não a minha, mas sim a sua obra é marcada por uma constante e desesperada busca da "singularidade brasileira" e mesmo da "singularidade cultural brasileira", como demonstrei no texto ora citado (nota 7), ao apontar várias passagens de sua obra em que esse conceito é motor retórico básico, assim como que a distinção entre sociedades (como comunidades regionais ou nacionais) "avançadas" ou "atrasadas" sobressai em seus textos. Esse tipo de populismo sociológico é nefasto porque joga na deturpação da obra dos outros para ganhar audiência e disseminar desinformação, no limite das fake news, que persuade os mais desinformados, com mais dificuldade de estudar a fundo a obra censurada. É um desserviço à ciência e ao debate acadêmico.

No plano institucional, no mesmo contexto, também houve obstáculos. A seleção acadêmico-profissional com jogos de cartas marcadas levou-me a ser preteridos em dois concursos públicos de maneira altamente controvertida. Apesar disso, as duas teses por mim apresentadas tiveram ampla recepção internacional e estão "andando o mundo". ${ }^{\text {ro }}$ Outro caso estranho foi minha demissão de uma instituição universitária sem qualquer fundamento ou "justa causa". Houve protesto internacional organizado por colegas da Alemanha e do Brasil, assinado por figuras como Jürgen Habermas. ${ }^{\text {II }}$ Por fim, fui vencedor em reclamação na justiça trabalhista, obtendo pagamento por danos morais e retratação da instituição. ${ }^{12}$

Hoje, apesar de todas as dificuldades de se trabalhar na universidade brasileira, especialmente no governo atual, trabalho com certa estabilidade e tranquilidade na UnB.

Nesse novo contexto, tenho procurado desenvolver um trabalho em torno da TdSS de uma forma heterodoxa. Acho que, na América Latina, ainda prevalece uma postura dogmática ingênua sobre conceitos como diferenciação funcional, autopoiese e Constituição como acoplamento estrutural, sem que se considerem os problemas e contextos específicos com que nos deparamos. Isso, parece-me, precisa ser mudado, mas os horizontes não são favoráveis por 
causa da própria postura colonizada de grande parte dos cientistas sociais e juristas no Brasil. Precisaríamos revolucionar o nosso modo de pensar e enfrentar criticamente, sem simplesmente os negar, os "grandes" autores do Ocidente hegemônico.

S\&A. Como observa a evolução da recepção em língua espanhola/portuguesa da obra de Niklas Luhmann? Quais foram suas características no passado? Como a observa na atualidade? Como projetaria essa recepção para os próximos anos? O que distingue e o que assemelha essa recepção da obra de Luhmann em relação à recepção na Alemanha (ou em língua alemã)? E qual a especificidade dessa recepção na AmLat com relação a outros meios acadêmicos relevantes, especialmente os de língua inglesa e francesa?

M.N. Eu remeto parte dessa pergunta à resposta que dei à primeira pergunta. Como disse, na década de I980, essa recepção no Brasil foi bacharelesca e superficial, enfim, lastimosa. A partir dos anos 2000, surgiram trabalhos mais interessantes que permitem falar de uma recepção com certa criatividade. Mas ainda prevalece um estilo exegético na recepção, especialmente no Brasil. A pergunta é tipicamente uspiana: "Quem melhor entendeu Luhmann no Brasil?" Isso é suficiente para a maioria. Mas é desastroso para o desenvolvimento da TdSS no Brasil.

Diferentemente, na Alemanha, há uma recepção mais reflexiva. Entretanto, um dos problemas dos discípulos de Luhmann na Alemanha, incluído o destacado Rudolf Stichweh, é que eles se apegam à primeira fase da teoria de Luhmann, na qual o primado da diferenciação funcional na sociedade mundial era assumido sem qualquer questionamento. Com as obras da década de I990, após o prefácio que Luhmann fez ao livro de minha tese de doutorado, ${ }^{13}$ há uma relativização desse primado e do conceito de autopoiese dos sistemas sociais, considerando que o metacódigo "inclusão/exclusão" cortaria transversalmente todos os sistemas funcionais e códigos sistêmicos. Stichweh chega a afirmar que Luhmann, com a introdução desse conceito, teria rejeitado o primado da diferenciação funcional, ${ }^{\mathrm{I} 4}$ o que Luhmann jamais afirmou. Este, ao contrário de mim, insistiu sempre no "primado" no plano da sociedade mundial, ${ }^{15}$ embora admitisse seus limites e ausência no nível de "peculiaridades regionais". ${ }^{16}$ Não considerava, porém, que aquilo tratado por ele, por assim dizer, como uma exceção subalterna que obstaculizava a diferenciação funcional no plano "regional", constitui a maioria dos contextos de comunicação na sociedade mundial, a saber, a África, a América Latina, grande parte da Ásia e, mesmo, setores da Europa Oriental. Assim, parafraseando o próprio Luhmann, que no final do Direito da sociedade, após citar minha obra, recua estrategicamente, para dizer que talvez se comprove que a existência de um sistema jurídico autônomo "não seja nada mais que uma anomalia europeia", ${ }^{17}$, eu diria, contra os discípulos 
ortodoxos de Luhmann na Alemanha, que o primado da diferenciação funcional é uma "anomalia" ou exceção do Ocidente hegemônico na sociedade mundial. Na França, a recepção de Luhmann foi prejudicada pela força não apenas científica, mas também política, da obra de Pierre Bourdieu. Paradoxalmente, essa obra poderia ter levado a um debate interessante com a teoria luhmanniana, mas tal alternativa não vingou, prevalecendo a indiferença em relação à obra de Luhmann. É claro que há figuras como Jean Clam, mas ele é antes um filósofo do que um cientista social, estando concentrado fortemente na relação entre Luhmann e Heidegger. André-Jean Arnaud tentou disseminar a obra de Luhmann na França, organizando dois dossiês na Droit et Société, ${ }^{18}$ mas a repercussão não foi a que seria de esperar diante da relevância da obra de Luhmann.

Nos Estados Unidos e no Reino Unido, apesar de haver boas traduções, o caráter um tanto "hermético" e "complicado" dos trabalhos de Luhmann tem prejudicado a recepção da TdSS. Cabe referência a Chris Thornhill, mas, no seu caso, a TdSS entra intermediada pelo modelo de Carl Schmitt, que me parece incompatível com a diferenciação luhmanniana entre política e direito. De certa maneira, a recepção da TdSS no espaço acadêmico anglo-americano foi muito marcada pela obra de Gunther Teubner. Em geral, os ingleses e americanos fazem ciências sociais com uma linguagem muito próxima da linguagem ordinária do cotidiano, o que dificulta o interesse pelas traduções de Luhmann em amplos setores acadêmicos.

S\&A. Em relação à tradução, que papel ela desempenhou nos diferentes momentos de recepção da TdSS na AmLat? Que obras ainda inéditas em espanhol e em português considera que deveriam ser traduzidas e que potenciais mudanças essas obras gerariam na recepção de Luhmann aqui? Que outros autores e autoras deveriam ser traduzidos para enriquecer a recepção da TdSS na nossa região?

M.N. As primeiras traduções de Luhmann no Brasil foram muito ruins. Por exemplo, as traduções de Sociologia do direito e de Legitimação pelo procedimento (esta revista por um catedrático da FD/USP) são desastrosas. Não conheço as mais recentes em português. No México e no Chile, as traduções de Javier Torres Nafarrate e Darío Rodríguez são satisfatórias, pois se trata de trabalhos realizados por especialistas na obra de Luhmann. Ainda assim, discordo de certas opções tomadas nessas traduções. Destaque-se a tradução do código binário do direito "Recht/Unrecht" por "direito/não direito". "Não direito" está fora do direito, remete ao ambiente do sistema jurídico. "Recht/Unrecht" foi traduzido no inglês corretamente como "lawfull/unlawfull" ou como "legal/ilegal". No português, preferi usar "lícito/ilícito", considerando também o ilícito relativo como descumprimento de prestações contratuais. "Legal/ilegal" seria mais restrito na tradição jurídica eurocontinental, embora em traduções francesas também 
se traduza o código binário do direito, nos termos luhmannianos, por "légal/ illégal". ${ }^{\text {I9 }}$ Optei, como disse, por "lícito/ilícito" (que também foi a solução de Alberto Febbrajo e Reinhard Schmidt em italiano: "lecito/illecito" ${ }^{\circ}$ ), a saber, "conforme ao direito/desconforme ao direito", pois se trata de valoração positiva e negativa de comportamentos no interior do sistema jurídico. ${ }^{2 \mathrm{I}}$

Dentre as traduções de que sinto falta em língua portuguesa e espanhola, destaco a de Política da sociedade. ${ }^{22}$ Essa tradução poderia esclarecer muitos aspectos da obra luhmanniana em relação ao Estado como centro do sistema político regional ou territorialmente segmentado. Também contribuiria para a compreensão da democracia levada a sério por Luhmann, sobressaindo a ideia de que o povo fecha o sistema político. ${ }^{23}$

Parece-me que muitos outros autores deveriam ser traduzidos para o espanhol e o português no âmbito da teoria dos sistemas. Além das obras de Gunther Teubner, algumas delas já traduzidas, seriam relevantes, por exemplo, as traduções dos trabalhos de Karl-Heinz Ladeur, Andreas Fischer-Lescano, Alfons Bora, Rudolf Stichweh, Elena Esposito e Armin Nassehi, embora haja um número crescente de textos sendo traduzidos. No campo de diálogo com a teoria dos sistemas, seria importante a tradução de Hauke Brunkhorst (na sociologia) e de Christian Joerges (no direito).

S\&A. Como o senhor observa a carreira da distinção inclusão/exclusão (e suas relações com o par modernidade central/modernidade periférica) na recepção dos textos de Luhmann na AmLat, um processo que centralmente passou pela leitura de seus trabalhos (e das ressonâncias que ele produziu nos textos tardios de Luhmann)? O senhor considera que ele contribuiu para o avanço de leituras heterodoxas da TdSS na região?

M.N. O que apresentei na minha tese de doutorado (I99I), publicada em I992 na Alemanha, foi uma crítica à teoria de Luhmann que prevalecia até o fim da década de I980: relação inseparável, na sociedade moderna como sociedade mundial, entre o primado da diferenciação funcional e o "princípio da inclusão". Neguei isso argumentando que, por força de processos coloniais, neocoloniais e imperialistas no interior da sociedade moderna (mundial), houve uma bifurcação entre centros hegemônicos e periferias subalternas que tornava insustentável a TdSS de Luhmann nos termos de então. Conforme minha teoria, seria plausível o primado da diferenciação funcional e do princípio da inclusão nos centros hegemônicos, mas, nas periferias subalternas, a exclusão seria estrutural e primária, o que minaria a diferenciação funcional. É claro que não neguei a exclusão nos centros dominantes, como alguns críticos apressados chegaram a afirmar. A exclusão nos centros seria secundária, não constituiria uma "preferência estrutural". Ao contrário do que imputou equivocadamente à minha obra outro crítico, 'modernidade periférica/modernidade central' não 
é uma dicotomia ontológica baseada em um conceito essencialista de região. Trata-se, conforme o gosto, de algo próximo a um "tipo ideal" no sentido de Max Weber, de uma "redução" nos termos de Guerreiro Ramos ou de um "esquematismo" conforme Luhmann. Ordena o material de conhecimento. Adverti que não há pura periferia nem puro centro na realidade. Pode-se falar até de semiperiferias. Além do mais, considerei a contingência do conceito ao me referir a tendências paradoxais à periferização do centro. ${ }^{24}$ Recentemente, nos meus novos estudos sobre "transdemocracia", tenho enfatizado que o "lixo" da exclusão jogado dos centros nas periferias por meio do colonialismo, neocolonialismo e imperialismo tende a retornar sem qualquer reciclagem, apontando especialmente para o drama dos refugiados e a tragédia do chamado "terrorismo". ${ }^{25}$ Enfim, a distinção conceitual modernidade central/modernidade periférica pode até perder o seu sentido de diferença na sociedade mundial em um futuro não remoto, mas isso pode significar que a exclusão estrutural se espraiará, além de fronteiras e sem distinção, por toda a sociedade mundial.

A esse respeito, minha obra não teve uma recepção que me pareça adequada no Brasil e na América Latina. Houve, em parte, má compreensão e deturpação. A recepção que houve foi difusa, tendo ocorrido principalmente no âmbito acadêmico do direito. Quanto à sociologia brasileira, o fechamento em discussões sobre teorias europeias ou norte-americanas, de um lado, e a busca de uma singularidade da "sociedade brasileira", de outro, torna minha obra não interessante, embora ela seja mais sociológica do que jurídica. Na América Latina, exceções são Darío Rodríguez e Javier Torres Nafarrate, sociólogos que compreenderam e levaram a sério a minha obra, fazendo uma avaliação que me parece justa academicamente. ${ }^{26}$ Não gostaria de esquecer a contribuição de Pedro Henrique Ribeiro sobre a relação entre o meu modelo e o de Luhmann, discutindo "como a 'condição periférica' da América Latina impulsionou deslocamentos na teoria dos sistemas". ${ }^{27}$ As críticas, ao contrário, têm sido, em regra, equivocadas e até mesmo desonestas, constituindo uma exceção a recepção crítica por Aldo Mascareño, ${ }^{28}$ que merece consideração e respostas academicamente respeitosas; por exemplo: deve-se ter cuidado com a afirmação de que eu teria sustentado "que na América Latina não haveria, de fato, diferenciação funcional”, pois, no próprio texto que ele citou de minha autoria para embasar sua assertiva, eu apenas afirmava que não houve "uma adequada realização da autonomia sistêmica de acordo com o princípio da diferenciação funcional" em contraponto à ideia de Luhmann de "plena" realização da diferenciação funcional, ${ }^{29}$ ou seja, como em toda a minha obra, somente estava a argumentar que não prevaleceu o primado da diferenciação funcional na modernidade periférica. ${ }^{30}$ 


\section{Acerca das propostas da teoria dos sistemas para a sociologia da América Latina}

S\&A. Qual é, no seu entender, a contribuição que a perspectiva dos sistemas sociais poderia oferecer à sociologia da AmLat, entendida como a sociologia que não apenas se dedica a estudar a região, mas igualmente a sociologia nela produzida?

M.N. A teoria dos sistemas sociais oferece algo muito relevante para o pensamento social, a saber, o seu artefato teórico básico apropriado à hipercomplexidade e hipercontingência da sociedade mundial hodierna, assim como à dupla contingência como catalisadora dos sistemas sociais. A sociologia dominante na América Latina, especialmente no Brasil, ainda parte de modelos que supõem o conceito de sociedade regional ou nacional, na qual o sistema político seria central e apto a controlar a contingência e a complexidade da sociedade. Além disso, em grande parte, ela se desenvolve a partir de um conceito de sociedade nacional como comunidade com identidade cultural. Entretanto, sem entrar aqui na discussão sobre o caráter problemático do conceito de cultura, pode-se falar que é difícil recorrer à identidade cultural para caracterizar a sociedade e mesmo para compreender o Estado como megaorganização política territorial. Na sociedade mundial e também no interior de cada Estado, há uma diversidade de culturas tanto na conexão com grupos quanto na relação com os sistemas sociais. A teoria dos sistemas sociais afasta-se desse modelo corrente na sociologia latino-americana e brasileira e abre um campo mais complexo para a teoria social, que, sem dúvida, leva a muitas desilusões alimentadas pelos modelos sociológicos mais simples do main stream.

S\&A. Diante do atual leque de pontos de vista de investigação sobre a AmLat, considerando tanto as perspectivas mais consolidadas quanto as mais recentes (como, por exemplo, os vieses pós-coloniais e suas variantes), o senhor acredita que é factível um diálogo entre a TdSS e essas outras perspectivas que enfocam espacialmente fenômenos regionais? Dialogar, por certo, não significa aqui estabelecer consensos, e sim elaborar uma agenda de temas comuns e aprofundar conjuntamente sua problematização. Em caso afirmativo, quais seriam, no seu entender, os eixos comuns mais produtivos para esse diálogo? Em caso negativo, quais seriam as razões para a impossibilidade de elaborar uma agenda comum?

M.N. Em primeiro lugar, cabe esclarecer que há vários pós-colonialismos no âmbito dos estudos sociais. Em sua dissertação, Maria Eduarda Dantas procurou criativamente classificar minha teoria como uma variante dos modelos pós-coloniais ou descoloniais. ${ }^{3 \mathrm{I}}$ Sem dúvida, há afinidades. Porém, um dos aspectos 
que me afasta de muitas perspectivas pós-coloniais é a ênfase na cultura e na identidade nacional de povos. Afirma-se a luta em favor de uma identidade nacional ou cultural diante do colonizador opressor, não se considerando satisfatoriamente as estruturas de dominação presentes e os conflitos no interior dos respectivos Estados. O espaço político de cada Estado constitui uma arena de muitas disputas não somente de natureza política em sentido estrito, mas também de perfil cultural e epistemológico. Não há uma cultura ou uma identidade nacional brasileira, indiana, estadunidense, francesa etc. Trata-se de uma ideologia simplificadora. A identidade brasileira estaria nos malufistas ou nos setores do MST? A teoria tem de desvelar a complexidade da sociedade mediante reflexão, ao contrário da ideologia, que simplifica a realidade para possibilitar a ação. Há interdependência: a teoria sem ideologia é paralisante, a ideologia sem teoria é inconsequente e rasteira. Parece-me, porém, que no pós-colonialismo identitário, que despreza, por exemplo, os direitos humanos em virtude da origem (europeia!) deles, a dimensão teórica perde o seu significado. Seria o mesmo que dizer que o futebol não deveria interessar aos brasileiros porque a sua origem é britânica. Entretanto, assim como o futebol, os direitos humanos pertencem à sociedade mundial, envolvendo mesmo aqueles que os rejeitam.

Não obstante, há autores pós-coloniais que não se vinculam ao identitarismo cultural, mas apontam para críticas contundentes a questões estruturais de imposição de modelos políticos e jurídicos dos centros hegemônicos nas periferias subalternas. Um exemplo que permite um diálogo com a TdSS na minha versão é a obra de Partha Chatterjee. O subtítulo de um dos seus livros é sugestivo: "Reflexões sobre política popular na maioria do mundo". ${ }^{32} \mathrm{Na}$ linguagem da TdSS, o que ele propõe é uma teoria política para a maior parte dos contextos comunicacionais da sociedade mundial. o que proponho na minha obra é, similarmente, uma teoria social (relacionada, principalmente, aos sistemas jurídico e político) para a maior parte da sociedade mundial, sem negar que tal situação é inseparável dos centros hegemônicos, parte minoritária dessa sociedade. No modelo do primado da diferenciação funcional e do princípio da inclusão, sustentado por Luhmann, sobretudo na fase anterior à minha tese de doutorado, e mantido incólume por discípulos destacados como Rudolf Stichweh, a teoria social parte da reflexão de contextos minoritários da sociedade mundial ("uma anomalia europeia"?!) e pretende estender essas reflexões a essa sociedade como um todo. Partha Chatterjee, nesse particular, está próximo de mim, especialmente quando estabelece a distinção entre sociedade civil (eu diria, dos incluídos) e "população governada" (eu diria, dos excluídos) tratada como objeto na experiência do que chamo de países periféricos. Pablo Holmes tem apontado em seus estudos para essa proximidade entre minha obra e a de Partha Chatterjee. ${ }^{33}$ É claro que há diferenças, sobretudo no que diz respeito aos pressupostos teóricos e ao contexto social que serve de ponto de partida para as teorias: no meu caso, o Brasil; no de Chatterjee, a Índia. Mas o diálogo 
é possível na busca de reflexões mais robustas sobre as assimetrias gritantes na sociedade mundial.

S\&A. A TdSS possui uma ambição de generalidade teórica que, à primeira vista, se colocaria acima das experiências históricas específicas. Contudo, como se sabe, há uma longa tradição teórica, na AmLat, que propõe justamente que a tensão entre teoria e história seria decisiva para a criatividade teórica na região. Como a TdSS ajudaria a recolocar esse problema?

M.N. A TdSS de Niklas Luhmann é uma teoria geral do social, ou melhor, uma metateoria da sociedade. Ela não pode dar conta por si só de abordagens históricas mais particulares. Entretanto, o seu artefato conceitual, trabalhado de forma reflexiva e sem dogmatismo, pode servir para pesquisas históricas mais específicas. Uma das minhas orientandas de doutorado, Nathaly Mancilla Órdenes, está trabalhando interessantemente sobre a regulação do distrito de Diamantina no século XVIII a partir do conceito de diferenciação funcional do direito. Por sua vez, Gilberto Pedrosa, em doutorado na Universidade de Frankfurt am Main e no Instituto Max Planck de História do Direito Europeu, sob a orientação de Thomas Duve, vem desenvolvendo tese pioneira sobre a "Globalização precoce e o status jurídico do trabalho forçado", considerando, à luz do conceito de sociedade mundial, a atuação econômica desdiferenciante da Companhia das Índias Ocidentais durante seu domínio territorial do Nordeste e Norte brasileiros no século XVII. Já na sociologia do direito, Edvaldo Moita, sob minha orientação e a de Alfons Bora, em regime de cotutela entre a UnB (direito) e a Universidade de Bielefeld (sociologia), está concluindo promissora tese de doutorado sobre o trabalho de vendedores ambulantes na cidade de Fortaleza, em que problematiza, com base em vasto material empírico, modelos simplistas de diferenciação funcional do direito. Nada impede que modelos teóricos abstratos alimentem pesquisas empíricas mais concretas, que, por sua vez, podem não apenas retroalimentar a teoria, mas também levá-la à neces sidade de fazer revisões. Isso ocorreu, por exemplo, na metateoria luhmanniana em face de minha tese de doutorado, que, embora não seja histórica, mas jurídico-sociológica e com pretensão teórica mais abrangente, levou à necessidade de revisão do modelo sistêmico dos anos I980, como reconheceu Luhmann expressamente em seu prefácio ao meu livro decorrente do doutorado:

\footnotetext{
Isso [a intepretação sociológica de Neves] remete a problemas para os quais nem a teoria marxista de classes, ou de proveniência pós-marxista, nem a concepção usual de diferenciação funcional da sociedade sabem dar uma resposta. Essas teorias são, por isso, refutadas? Mas como, senão por outra teoria?

Talvez a constelação de fatos aqui esboçada já permita perceber que outras distinções se sobrepõem às teorias de nossa tradição, construídas de maneira demasiadamente simples. ${ }^{34}$
} 


\section{Sobre o conceito de região da sociedade mundial}

S\&A. O senhor considera que a AmLat poderia ser tratada como uma região da sociedade mundial? Qual seria o nível operativo do conceito de região nas relações com os sistemas funcionais e em relação ao conceito de sociedade mundial? Dada a importância da diferenciação segmentária de Estados nacionais nos quadros do sistema político mundial, como deveriam ser tratados os Estados nacionais a partir de uma perspectiva sistêmica para a AmLat?

M.N. Não há um conceito de região tout court na teoria luhmanniana. Não há como diferenciar uma região sem mais como sistema. Quando Luhmann fala em regiões ele está se referindo a territórios delimitados como base geográfica de sistemas políticos segmentados espacialmente na forma de Estados. O Brasil, como qualquer outro Estado, é o centro de um sistema político segmentado regionalmente (ou territorialmente) na sociedade mundial. Regiões em um sentido mais amplo como América Latina, Europa Ocidental e África Subsaariana só são consideradas relevantes para a teoria dos sistemas enquanto englobem unidades políticas territoriais semelhantes quanto à formação histórica e ao contexto social. Em Luhmann, a geografia não é tão importante, como bem arguiu Rudolf Stichweh, apontando para uma "necessidade de correção". ${ }^{35}$ Entretanto, a segmentação política em territórios ou regiões do globo terrestre é muito relevante para o modelo luhmanniano.

Daí por que não se deve desconsiderar o papel relevante das megaorganizações territoriais chamadas "Estados" no âmbito da teoria dos sistemas sociais. Certo, há uma ênfase na diferenciação funcional, mas a segmentação territorial em Estados é transversal aos sistemas funcionais e pode ter efeitos tanto positivos quanto negativos no desempenho dos sistemas funcionais da sociedade mundial. A TdSS luhmanniana não se empolga com a linguagem do "fim do Estado". Por exemplo, a relevância e os efeitos danosos dos EUA para inclusão e os direitos humanos na sociedade mundial foram expressamente salientados por Luhmann. ${ }^{36} \mathrm{E}$ quem pode negar, senão um dogmático, o quanto a ação estatal pode impactar os sistemas funcionais no plano global e regional. E, ao contrário dos modelos de soft law, que enfatizam a transnacionalidade do direito, o hard law e a hard policy dos Estados ainda impactam primordialmente os sistemas jurídico e político, mas também as condições de reprodução de outros sistemas sociais não segmentados territorialmente.

S\&A. Por que o conceito de "alopoiese" permitiria/habilitaria uma melhor identificação de regiões que o conceito de autopoiese? É possível identificar processos alopoiéticos em outras regiões, especialmente nas regiões habitualmente associadas ao "primeiro mundo"? Haveria alopoiese, por exemplo, nos sistemas funcionais da ciência, da arte, dos esportes? O conceito de alopoiese per- 
mitiria articulações com o conceito de classe social? Com quais variantes deste último o senhor considera que teria mais afinidade e com quais teria menos afinidade?

M.N. O próprio Luhmann admitiu com base em minha obra que, no caso de "corrupção extrema" no sentido sistêmico, surge uma situação em que não cabe mais falar de "fechamento autopoiético" do direito. ${ }^{37}$ Só há autopoiese porque podem ocorrer fatores alopoiéticos. Luhmann chega a afirmar que a sabotagem de código ou corrupção no sentido sistêmico seria um "problema moral" na sociedade mundial, mas ele afirma que se trata de uma "patologia" ${ }^{8}$ (ironicamente, afirmei que, na modernidade periférica, seria uma "patologia da normalidade", utilizando uma expressão de Erich From em relação à psicanálise da sociedade contemporânea ${ }^{39}$ ). Além disso, como já considerado acima, ele reduz a alopoiese a "peculiaridades regionais", como se fosse algo excepcional, embora se contradiga quando se refere a "uma anomalia europeia" em relação à autopoiese do sistema jurídico. Na verdade, eu tratei de processos alopoiéticos do direito na periferia como marca estrutural. É claro que sempre há sabotagem de código ou corrupção em sentido sistêmico, inclusive na modernidade central (no que vocês chamam "primeiro mundo"). O que eu disse é que os processos alopoiéticos do direito estatal, segmentado territorialmente, decorrentes de injunções bloqueantes da política, da economia e das boas relações, eram estruturais, implicando uma tendência à generalização com apoio dos próprios agentes estatais vinculados à aplicação e à execução do direito como o judiciário e a polícia. Em outras palavras, autopoiese do direito é o funcionamento efetivo do Estado de direito ou do rule of law. É claro que na Dinamarca, na Alemanha e principalmente nos EUA há quebras das regras do jogo jurídico, mas elas são eventuais ou estruturais setorizadas, não quebrando a autonomia do sistema jurídico como um todo. Nas condições de reprodução periférica, essa situação tem tendências à generalização na relação entre a megaorganização Estado e os particularismos advindos de uma sociedade civil excludente. Daí por que eu relacionei a alopoiese do sistema jurídico às formas assimétricas de exclusão "por baixo" e "por cima", nos termos dos pares conceituais "sobreintegração/subintegração" e "sobrecidadania/subcidandania"40. Mas sempre admiti que a prevalência eventual de tendências à paradoxal periferização dos centros pode tornar irrelevante essa distinção entre primado da autopoiese nos centros hegemônicos e primado da alopoiese nas periferias subalternas.

Quanto à arte, ciência e esportes, a situação é mais problemática. Como não são sistemas diferenciados segmentariamente em territórios, seria difícil definir com precisão o que seria o primado de processos autopoiéticos nos centros hegemônicos e o primado da alopoiese nas periferias subalternas. Seriam necessárias pesquisas mais específicas. O caminho que vislumbro é o da relação desses sistemas com o sistema político no plano estatal: em que me- 
dida a política científica, artística e esportiva pode impactar a autonomia da ciência, da arte e dos esportes de forma mais marcante na modernidade periférica? Mas também caberia considerar a relação desses sistemas com o direito estatal: em que medida a carência da liberdade artística, científica e esportiva pode impactar a autonomia da arte, da ciência e dos esportes nas periferias subalternas? É claro que essas questões exigem pesquisas mais aguçadas sobre os níveis de diferenciação funcional em uma sociedade mundial assimétrica. (Mas me parece equivocado arguir, por exemplo, que a "alta qualidade" estética da obra artística, como a de Fernando Bottero e a de Francisco Brennand, é uma prova da autonomia da arte nas periferias subalternas. A arte clássica grega e a romana, a arte medieval e mesmo a de povos arcaicos são, com frequência, reconhecidas como de "alta qualidade" estética, mas isso não pode levar à conclusão de que houve autonomia operacional da arte e primado da diferenciação funcional nas respectivas sociedades.)

Com o tempo, porém, eu me afastei da diferença entre autopoiese e alopoiese. Embora sem a rejeitar em termos absolutos, convenci-me de que são conceitos que mais complicam do que esclarecem problemas sociais relevantes. Hoje trabalho mais com níveis estruturais de diferenciação sistêmico-funcional em uma sociedade mundial assimétrica. Ela vai desde uma situação de forte falta de diferenciação - como no Burundi, onde, por exemplo, em 3 de fevereiro de 2018 , após uma partida informal de futebol ("pelada") entre o time da cidade de Kiremba e o do presidente do país, Pierre Nkurunziza (Haleluya FC), dois funcionários desse município foram presos sob acusação de "conspiração contra o presidente" porque o seu time jogou duramente contra o time do chefe de Estado, alegando-se arbitrariamente que Nkurunziza fora espancado por jogadores de Kiremba em disputas de bola (usualmente, os adversários facilitavam a vitória da equipe do presidente, que organizava as partidas) ${ }^{4 \mathrm{I}}-\mathrm{a}$ uma situação de extrema diferenciação - como na Alemanha, onde o ministro-presidente de Schleswig Holstein, Uwe Barschel, em I987, após se comprovar que espionou seu adversário político e, portanto, violou as regras dos jogos jurídico e político, foi sujeito à persecução jurídica, entrou em desgraça política e caiu no desprezo moral, suicidando-se em um hotel na Suíça. ${ }^{42}$ Há um momento, portanto, em que a diferença quantitativa é tão enorme, que cabe reconhecer o caráter qualitativo digno de um esquematismo como centro e periferia da sociedade mundial. Tudo isso, porém, é inseparável de problemas de exclusão versus inclusão: onde há mais desigualdade e exclusão, os bloqueios dos sistemas funcionais tendem a acentuar-se; quando há mais inclusão e menos desigualdade, a corrupção em sentido sistêmico tende a reduzir-se.

Nesse particular, a questão das classes sociais me parece relevante. Ao contrário de Luhmann, entendo que a questão de classe é fundamental tanto para alicerçar quanto para minar a diferenciação social. Para mim, o sistema econômico mundial capitalista tem tendências desdiferenciantes, exploradoras 
e destrutivas da democracia como "autopoiese", do sistema político fechado pelo povo e do Estado de direito como "autopoiese" do sistema jurídico fechado pela Constituição. Há um trabalho de doutorado em andamento, de Douglas Elmauer, sob a orientação de Andreas Fischer-Lescano, que trata dessa "reificação" dos demais sistemas sociais pela lógica do capital.

Mas há uma diferença, parece-me. O Estado democrático de direito dos centros hegemônicos faz uma concorrência forte ao imperialismo e expansionismo do sistema econômico capitalista na sua reprodução nas respectivas regiões estatais. Nas periferias subalternas, o Estado é muito frágil para se contrapor à força destrutiva da economia capitalista, que mina os direitos básicos e compromete inteiramente o eventual procedimento democrático.

A respeito de classe no sistema econômico capitalista, eu poderia desenvolver uma tese simplista e agradar muitos ideólogos com jargões marxistas: nos setores de inclusão haveria "classe para si", enquanto nos setores de exclusão haveria apenas "classe em si". ${ }^{43}$ Mas isso não me parece convincente nem satisfatório no nível da reflexão. Também não considero que os excluídos se confundem com "Lumpen" ou "Lumpenproletariado" como um "exército industrial de reserva" (no sentido ideológico negativo da tradição marxista ${ }^{44}$ ). Para mim, enquanto no Estado democrático de direito dos centros hegemônicos, onde ainda há o primado da inclusão, a luta de classes foi domesticada na forma de conflito ou disputa trabalhista, nas periferias subalternas, onde há o primado da exclusão, a luta de classes não foi domesticada, permanecendo com potencial muito mais radical para pôr em xeque o próprio capitalismo em seu caráter desdiferenciante e opressor das diversas esferas discursivas, como arte, ciência, direito e política. Nesse sentido, há um potencial "revolucionário" nas periferias subalternas, que está sob controle nos centros hegemônicos da sociedade mundial.

Para concluir, gostaria de acrescentar que não se pode tratar o primado da diferenciação funcional como uma panaceia para esclarecer todas as questões, problemas, reflexões e pesquisas no âmbito da teoria dos sistemas sociais. Indo além de Luhmann, sem negar a noção de hipercomplexidade e hipercontingência, cabe dizer que não há esse primado, mas sim, relevantemente, diferenciação funcional em concorrência com outras diferenciações, como a segmentar (em Estados, sobretudo) e hierárquica (em classes, sobretudo), e com outras diferenças, como exclusão/inclusão e centro/periferia da sociedade mundial. Sem dúvida, a diferenciação funcional está sempre presente, direta ou indiretamente, na sociedade mundial. Porém, em determinados processos, contextos e setores da sociedade mundial, ela tem o primado, enquanto, em outros, ela se subordina ou é minada por outras formas de diferenciação e diferenças.

A esse respeito, cabe recuperar uma passagem de Luhmann sobre a propriedade: 
O esquematismo ter/não ter se torna autônomo na medida em que ele não signifique para os contextos funcionais extraeconômicos, a saber, que não transfiram as desigualdades de propriedade para outros subsistemas da sociedade portanto, que não se celebrem missas mais frequentemente para os proprietários, que não se reservem aos proprietários melhores chances de educação, melhores chances processuais no sistema jurídico, melhores chances de serem eleitos para cargos políticos, melhores chances de tratamento em casos de doença etc., do que para os não proprietários. ${ }^{45}$

Enfim, considerando esse trecho, não seria de indagar: o pleno primado da diferenciação funcional, com a ampla autonomia da arte, da ciência, da política democrática, dos direitos, do sistema de saúde e dos esportes não exigiria uma superação do capitalismo como sistema econômico global? Portanto, a ideia de um socialismo como sistema econômico da sociedade mundial seria digna de consideração, embora nos termos contingentes, não essencialistas, de um futuro aberto, insuscetível de profecia. 


\section{REPORTAJE A ALDO MASCAREÑO}

\section{Acerca de la trayectoria académica y la recepción de la teoría de sistemas sociales}

Sociología \& Antropología. ¿Cómo tomó contacto con la obra de Luhmann? ¿Cómo observa la recepción de la Teoría de Sistemas Sociales (TdSS) o de la perspectiva de sistemas sociales en América Latina (AmLat)? ¿Cuáles son en su opinión los desarrollos de la TdSS más innovadores en o desde la región, incluyendo su proprio trabajo?

Aldo Mascareño. Mi trayectoria siempre estuvo marcada por profesores directamente relacionados con Niklas Luhmann. Lamentablemente, yo no alcancé a tener un vínculo directo con él, pues en I997, cuando llegué a Alemania a realizar mi doctorado, Luhmann ya no estaba públicamente disponible - seguramente se encontraba dando los últimos retoques a su obra La sociedad de la sociedad.

Mi primer contacto con el pensamiento luhmanniano fue a inicios de los años I990 a través de mi profesor y amigo Darío Rodríguez quien en la década de 1980 había hecho su doctorado con Niklas Luhmann sobre la transformación neocorporativista de las organizaciones chilenas a fines de los años I960, unos años antes del golpe militar de Pinochet. Darío Rodríguez, ampliamente conocido en América Latina por sus investigaciones sistémicas y sus análisis organizacionales, fue quien me mostró por primera vez la teoría de Luhmann. Otro profesor y amigo, Miguel Chávez, quien trabajó durante varios años junto a Luhmann en Bielefeld, me formó en el empleo y aplicación de la teoría de sistemas sociales a la realidad contemporánea. Con ellos, Luhmann quedó para mí como un "libro abierto" para la búsqueda de la comprensión de la sociedad mundial en el cambio de siglo.

En Alemania, durante mis estudios doctorales, mi profesor fue Helmut Willke. Con él aprendí a distinguir entre la teoría de sistemas y su autor Niklas Luhmann. Sin duda, Luhmann es un maestro para todos; de esos con quienes uno se puede topar solo una vez en la vida. Pero su teoría es una oferta de comunicación y, como tal, queda expuesta no para reproducirla, sino para desplegarla en todos los vértices que Luhmann abrió. Esa ya no era tarea de Luhmann, sino de todos quienes trabajamos en este ámbito intelectual. Solo ello puede mantener a la teoría viva y en sintonía con los tiempos que corren. Creo que este es el mensaje que Luhmann quería transmitir: no dejar que la teoría se transformara en un clásico. Además de su conocimiento y colaboración, esta es justamente la principal enseñanza que me legó el profesor Helmut Willke.

En América Latina, especialmente en países como Chile, Brasil, México, Colombia, la teoría de sistemas ha tenido una muy buena recepción. A dos 
décadas del siglo XXI, ya se cuentan tres generaciones de intelectuales que en distintos países del continente despliegan la teoría de Luhmann: los que primero lo conocieron y estudiaron con él; mi generación que llegó posteriormente a Alemania a estudiar teoría de sistemas; y la generación más joven que hoy estudia y trabaja en el ámbito sistémico en distintos países de la región y también en Europa.

En la generación joven de América Latina cuento fácilmente unos quince nombres entre hombres y mujeres que hoy siguen desplegando la teoría de sistemas sociales sobre temas como la desigualdad, la inclusión/exclusión, los problemas socioecológicos, los nuevos movimientos sociales, la educación superior, los procesos sociopolíticos y constitucionales de la sociedad mundial, y sobre sus problemas financieros, mediáticos y semánticos. Más los despliegues en teoría general, entre otros. Es decir, gran parte del catálogo luhmanniano está bien cubierto por las nuevas generaciones de intelectuales latinoamericanos interesados en la teoría de sistemas.

En cuanto a los desarrollos más innovadores de la teoría de sistemas en América Latina, uno debiera entender que son siempre los últimos y de los intelectuales más jóvenes. Pero sin duda los más consolidados y visitados son los que se relacionan con el proceso de diferenciación funcional en América Latina. Aquí quiero mencionar al gran colega brasileño Marcelo Neves, que fue el primero en desarrollar esta veta de análisis con su teoría de la constitución simbólica, la modernidad periférica y la alopoiesis de sistemas como el derecho. Esta es una teoría que se ha sostenido en el tiempo y que ha tenido innovadores desarrollos.

Mi propia interpretación del proceso de diferenciación funcional en América Latina intenta ser una respuesta a la tesis de Luhmann y Stichweh de que la diferenciación se habría originado en Europa una única vez y desde ahí se habría expandido al "resto del mundo". Sostengo que si la diferenciación funcional se origina en el siglo XVI - especialmente en sistemas como la religión, la economía, la política y el derecho -, los españoles y portugueses que llegaron a América originalmente no pueden haber traído con ellos la diferenciación funcional. Su experiencia social en Europa no es la de la diferenciación funcional, sino la de una sociedad estratificada, monárquica y estamental, que era muy similar - en términos de principios de diferenciación - al modelo que ya existía en América en el período tardío de las grandes culturas amerindias, organizadas sobre un esquema estratificado en los centros y segmentario en relación con las periferias.

Entonces, no se puede decir simplemente que la diferenciación funcional llegó a América con la conquista. Más bien, esta se desarrolló en el encuentro desigual entre americanos y europeos y, tanto en América como en Europa, lo desplegaron en conjunto. Creo que esto es innovador, pues siempre hemos aceptado que lo que llamamos la conquista trajo consigo una política diferen- 
ciada, una economía diferenciada, un derecho diferenciado, cuando en realidad la diferenciación se construyó históricamente en la relación. No es inducida; es endógena a la relación entre americanos y europeos desde el siglo XVI en adelante.

El corolario de esto reside en entender que en el proceso de diferenciación funcional de América Latina hay tendencias históricas paradójicas: unas que operan en dirección de la diferenciación de sistemas y otras - que he llamado concéntricas - que buscan mantener el orden jerárquico de la sociedad estamental desde la que emerge el proceso de diferenciación funcional en América y el mundo. Con ello se conforman redes de estratificación y reciprocidad basadas en la interacción que capturan rendimientos funcionales emergentes. Por esto, el concepto de desdiferenciación juega para mí un rol central, pues tal como he tratado de entenderla, la desdiferenciación no es permanente, es episódica: hay momentos de desdiferenciación, momentos que podríamos llamar con Neves alopoiéticos. Pero sigo sosteniendo que esta no es una condición permanente del proceso de diferenciación en América entre los siglos XVI y XXI, menos ahora que América Latina es una región de la sociedad mundial.

Otros despliegues interesantes de la teoría de Niklas Luhmann en la región son los que muestran la relación entre el debate constitucional y los nuevos movimientos sociales. En esto, Marcelo sigue teniendo una posición central con su teoría del transconstitucionalismo. Dentro del ámbito sistémico también me parecen muy innovadores los aportes de mi colega brasileño Germano Schwartz, quien en los últimos años viene desarrollando una muy fuerte y exhaustiva investigación sobre el rol constituyente de los nuevos movimientos sociales a escala global y con especial énfasis en América Latina. El trabajo de Germano tiene la particularidad de incluir análisis comparativos con movimientos sociales de otras regiones, y eso permite ver a América Latina muy vívidamente como una región más entre otras. Una región que tiene problemas similares a Europa, Medio Oriente y Asia, pero que también tiene sus particularidades, como toda región de la sociedad mundial.

Otra área en la que la teoría de sistemas ha comenzado a realizar aportes destacados en América Latina es la socioecología. Las teorías socioecológicas (Folke, Scheffer, Gunderson, Holling) son tributarias de la teoría general de sistemas complejos. Por ello, la integración con la teoría de sistemas sociales es una cuestión de "aire de familia". En este campo quiero destacar el ingente y original trabajo que está desarrollando la colega chilena Anahí Urquiza, con investigación empírica y teórica en sistemas socioecológicos. La integración que hace de ambos universos teóricos abre nuevas perspectivas tanto para la teoría de sistemas como para la aproximación de sistemas socioecológicos. No se trata solamente de una expansión de lo que Luhmann sostuvo en Comunicación ecológica, sino de "tomarse en serio" el medioambiente como un espacio indisolublemente unido a la observación social, que opera en conjunto con 
dinámicas críticas, de incubación, propagación socioambiental de efectos y consecuencias con largos períodos de recomposición.

No quiero dejar de mencionar el ámbito de la elaboración conceptual de la teoría de sistemas. En foros y encuentros internacionales, a menudo tengo la impresión de que una parte no menor de los colegas europeos que trabajan en teoría de sistemas entienden que la teorización sistémica está concluida con el enorme despliegue que desarrolló Niklas Luhmann. Pero el hecho de que en América Latina observemos en nuestros análisis varios elementos que no calzan perfectamente con algunas formulaciones conceptuales de la teoría de sistemas original, propicia para los "sistémicos latinoamericanos" una oportunidad y una inclinación que no se les presenta a los colegas europeos. Esta es pensar en términos sistémicos operaciones sociales que observamos empírica e históricamente en nuestra región y para las cuales requerimos de reconceptualizaciones. Creo que eso nos ha dado a los latinoamericanos la posibilidad de aportar con interesantes conceptos a la teoría. Ya he mencionado las contribuciones de Neves, Schwartz y Urquiza en este ámbito. También creo destacable el trabajo de Pablo Holmes en cuestiones constitucionales y de governance; de Sergio Pignuoli en temas epistemológicos de teoría de sistemas; de Jorge Galindo en modernización; de Hugo Cadenas en desigualdad; de Leandro Rodríguez en circulación de conocimiento; de Patricia Herrera en derechos humanos; de Artur Stamford en decisión jurídica; de Gabriela Azócar en sistemas socioecológicos; de Antonio Brasil Jr. en a la recuperación de la tradición de pensamiento latinoamericano que dialoga con la teoría de sistemas; y por supuesto, el invaluable trabajo teórico y de traducción al español de la obra de Luhmann realizado por Javier Torres.

Vistas las cosas de este modo, la teoría de sistemas está más viva que nunca en América Latina, tanto por la amplitud generacional de quienes trabajan con ella y por la investigación empírica que llevan adelante, como por el despliegue y actualización conceptual que resulta de ello. Me parece que es la teoría que presenta en mayor grado una comunidad de intelectuales que no solo trabajan bajo su influencia, sino que se conocen y comparten en distintos espacios. La situación puede ser parecida a lo que fue el marxismo latinoamericano en los años I960. Quién lo iba a decir.

S\&A. En las experiencias que ha tenido en su destacada trayectoria, ¿qué desafíos, qué obstáculos y qué sorpresas enfrentó de parte de colegas y de estudiantes? ¿Ha notado cambios al respecto a lo largo del tiempo? Dentro de los obstáculos que encontró, ¿cuál fue el más duro que le tocó enfrentar, ¿cuál fue el que mejor logró sortear o eludir y cuál considera que no logró vencer? A su entender, ¿cuáles son los desafíos que afrontará la perspectiva de sistemas sociales en un futuro cercano dentro de la región? 
A.M. A mi juicio, el mayor obstáculo que un intelectual sistémico enfrenta en América Latina consiste en lo profundamente arraigados que están en el mundo intelectual y político de la región lo que Luhmann llama obstáculos epistemológicos. En realidad, estos obstáculos no son un problema puramente conceptual. Toda la vida social se organiza prácticamente desconociendo esto obstáculos; siendo ciega a ellos. Es decir, fuera de la teoría de sistemas no parece haber alternativa a pensar que la sociedad se compone de hombres, que social significa consenso entre personas, que la sociedad son países, y que podemos observar todo esto desde afuera sin ensuciarnos las manos. Mostrar eso a colegas y a estudiantes, y comportarme en mi vida cotidiana intentando superar estos obstáculos, creo que es el mayor desafío al que siempre se enfrenta un pensador sistémico.

Vivimos en una región donde desafiar estas premisas se vuelve inmediata e irreflexivamente un problema político. Por una parte, esto puede ser influjo del marxismo latinoamericano y de su instalación política como "teoría moralmente correcta". Por otra, puede ser parte de la recepción esquemática de la teoría de Jürgen Habermas, quien a mi juicio y junto con Hauke Brunkhorst, son los teóricos no-sistémicos más sistémicos después de Luhmann, quienes en todo caso se apartan de él cuando entran en modo kantiano. Pero creo también que hay una razón práctica para esto: es la profunda desigualdad social existente en América Latina, aquella que tanto Gino Germani como la teoría de la dependencia, entre otros, describieron de manera magistral.

Si seguimos observando la desigualdad e injusticias en América Latina cegados por los obstáculos epistemológicos, lo que observamos es un mundo en el que el principal problema es que hay malas y buenas personas, que nunca se ponen de acuerdo, que solo los gobiernos de los países latinoamericanos tienen la responsabilidad en el estado de cosas que enfrentamos, y que la tarea de los intelectuales es criticar lo que observan. Este es un programa intelectual que ya no rinde para comprender la complejidad en la que vivimos. Superar este gran desafío observando América Latina desde la teoría de sistemas significa entender que el principal problema hoy no es la explotación o la falta de consenso, sino la profunda e inmanente indiferencia de los sistemas sociales frente a lo que acontece en cada región.

Si seguimos asumiendo que la realidad la hacen las personas, dejamos de ver que a la autopoiesis de los sistemas sociales no le importa el destino de las personas, sino que solo le importa que se comunique en el registro respectivo. Que en tanto haya algunos que compren, los miles de excluidos no son relevantes. Que en tanto haya algunos que participen políticamente, la desafección política puede mantenerse por largo tiempo. Que en tanto existan decisiones jurídicas que reproduzcan el sistema, el acceso de todos a los mismos estándares de justicia no es un problema central para los sistemas sociales.

El principal desafío que enfrentamos hoy en América Latina y en distintas regiones del mundo es la indiferencia de los sistemas. No se puede insistir 
poco en esto. El pensamiento tradicional puede seguir apoyándose en la distinción capital/trabajo esperando que tras ella aparezcan personas moralmente compelidas a llegar a consensos para evitar la explotación de otros y del medioambiente, pero la indiferencia sistémica indica que hay lógicas evolutivas para las cuales las miserias de las personas y los países no son un dato significativo.

Entonces, el desafío a enfrentar de nuestra sociedad es, primero, lograr observar estas lógicas sistémicas transnacionales y, segundo, buscar el modo de introducir en esos sistemas formas de operación que reduzcan la indiferencia del sistema. Es cierto que la crítica sirve a esto, pero es simplemente una observación de segundo orden que, en la mayoría de los casos, apela a una racionalidad que es rechazada por la indiferencia del sistema, lo que solo puede incrementar esa crítica. Se requiere más bien de operaciones de primer orden para superar esta indiferencia. Intervenciones contextuales, sistemas de deliberación, negociaciones, transformaciones procedimentales, conflictos e incluso las crisis son mecanismos más eficientes que la crítica para hacer ver al sistema lo que no ve, y para reorientarlo desde adentro.

Para un/a teórico/a de sistemas esto tiene que ser una actitud cotidiana. Pues es ella o él quién mejor sabe de la alta indiferencia con que funcionan los sistemas sociales. El teórico de sistemas tiene que ser un interventor por excelencia. La ceguera de los sistemas lleva, más temprano que tarde, al colapso; los sistemas entran en un bloqueo conductual que les impide su adecuación al entorno. Actuar sistémicamente (comunicar y operar) para sacar a los sistemas de ese lock in es una responsabilidad que no se puede eludir. La crítica ya no es suficiente. De lo que se trata es de transformar la indiferencia sistémica en observación, en una systemische Aufklärung, para con ello atacar las causas modernas de la desigualdad y la injusticia.

S\&A. ¿Cómo observa la evolución de la recepción en lengua española/portuguesa de la obra de Niklas Luhmann? ¿Cuáles fueron sus características en el pasado? ¿Cómo la observa en la actualidad? ¿Cómo proyecta que lo será en el futuro cercano? ¿Qué distingue y qué asemeja a esta recepción de la obra de Luhmann respecto de la que tuvo o tiene lugar en Alemania o, en un sentido más amplio, en lengua alemana? ¿Y cuál es su especificidad en relación con la recepción de dicha obra en otros medios académicos relevantes, especialmente en lengua inglesa y en lengua francesa?

A.M. La traducción de la obra de Luhmann al español ha jugado un rol central en la conformación de una comunidad académica latinoamericana de teoría de sistemas. Tuvimos la traducción de Sistemas sociales temprano, en I99 I - al inglés fue en I 995 -, y la traducción de La sociedad de la sociedad en 2007 - al inglés fue en 20I2. También El derecho de la sociedad (2002) ha sido muy influyen- 
te en América Latina; esto permitió el fuerte desarrollo de la sociología sistémica del derecho en la región. Creo que todo esto es decisivo en el interés de muchos académicos jóvenes - insatisfechos analíticamente con el marxismo y con la teoría de la acción comunicativa - por aprender teoría de sistemas y aplicarla a la región latinoamericana.

Gracias a esta obra de traducción, la teoría de sistemas es hoy un "medio de comunicación simbólica y diabólicamente generalizado" en América Latina. Tomo la distinción de comunicación simbólica y diabólica de La economía de la sociedad, libro que traduje yo mismo al español en 20I7. Es simbólica porque ha logrado conformar una comunidad académica que sigue creciendo en la región; y es diabólica porque separa a esa comunidad de otras que la observan como no comprometida, conservadora o promotora incluso del status quo. Ya he señalado que la crítica me parece una herramienta válida para atacar la indiferencia de los sistemas; pero ella por sí sola es inútil, es profundamente conservadora, pues sigue presa de los obstáculos epistemológicos y de la creencia de que por criticar no se tiene responsabilidad en los problemas. La crítica peca siempre de falta de autología.

Simbólica y diabólica es también la traducción de la obra de Luhmann, pues, por un lado, la abre a una multiplicidad de interpretaciones, y por otro, las reúne bajo el rótulo "teoría de sistemas". Esa es justamente la riqueza de la comunicación sistémica en América Latina: ya no es dependiente de dos o tres divulgadores que tengan una interpretación más o menos ortodoxa (o heterodoxa) de la obra. Para la libertad de interpretación - para la libertad en general - no hay nada mejor que la contingencia de la comunicación. Hoy los libros de Luhmann están disponibles en español para quien quiera ver las operaciones regionales por medio de estos potentes lentes que aumentan la capacidad de observación.

El trabajo de Johannes Schmidt y André Kieserling con el Luhmanns Archiv en Bielefeld ha sido extraordinario. En las últimas dos décadas, a partir de los manuscritos de Luhmann han aparecido nuevos libros de su autoría, especialmente de sus etapas tempranas. Por ejemplo, Kontingenz und Recht (Contingencia y derecho), Politische Soziologie (Sociología política), Die Politik der Gesellschaft (La política de la sociedad), Ideenevolution (Evolución de las ideas), Macht im System (Poder en el sistema), por nombrar algunos. Aquí hay un gran desafío de traducción al español para las generaciones más jóvenes.

Recientemente traduje Macht im System al español. Es un libro que data de fines de los años I96o y en el que ya se pueden ver muchos elementos de la posterior teoría general de Luhmann puestos en juego para analizar el medio poder: las limitaciones del pensamiento clásico, la diferenciación entre poder, influencia y autoridad, las dimensiones del sentido, la generalización simbólica, la reflexividad, la diferenciación y la decisión. Es un libro que seguramente motivará varias lecturas de la actual situación política latinoamericana en diversos ámbitos. 
Entre los libros clásicos de Luhmann que no han sido traducidos al español está el volumen con Jürgen Habermas Theorie der Gesellschaft oder Sozialtechnologie? (¿Teoría de la sociedad o tecnología social?). Algunos pasajes de este texto están en inglés, pero creo que por su relevancia no solo en el debate Luhmann-Habermas, sino para el propio auto-esclarecimiento de la posición luhmanniana, la traducción de esta obra es importante. Lo mismo cuenta para Rechtssoziologie (Sociología del derecho), traducido al inglés como A sociological theory of law, 20I4. Es un libro de I972 en el que Luhmann construye por primera vez sistemáticamente su teoría del derecho y en el que la diferencia entre expectativas normativas y cognitivas juega un rol preponderante.

Otros autores que debieran ser traducidos al español son, sin duda, Helmut Willke, Rudolf Stichweh, Elena Esposito, Urs Stäheli, Gunther Teubner, Chris Thornhill, Poul Kjaer. Ellos ampliaron el campo temático y heurístico de la teoría de sistemas y lo siguen haciendo hoy. Libros clave al respecto son: Ironie des Staates (La ironía del Estado, Willke), Die Weltgesellschaft (La sociedad mundial, Stichweh), Die Konstruktion der Zeit in der zeitlosen Gegenwart (La construcción del tiempo en la actualidad atemporal, Esposito), Sinnzusamenbrüche (Quiebres de sentido, Stäheli), Constitutional fragments (Fragmentos constitucionales, Teubner), A sociology of transnational constitutions (Una sociología de las constituciones transnacionales, Thornhill), Constitutionalism in the global realm (Constitucionalismo en el ámbito global, Kjaer).

S\&A. ¿Considera que su concepto de Jung-Luhmannianer mantiene vigencia? ¿Por qué? ¿Introduciría alguna variable regional para actualizarlo o potenciarlo? ¿En qué ámbitos de investigación y en qué medios académicos hubo más Jung-Luhmannianer?, y, evaluándolos de manera retrospectiva, ¿cuál es su balance acerca de esa postura hacia la obra de Luhmann y hacia los desarrollos Luhmann inspired?

A.M. Todo lo dicho en estas páginas, y lo que creo hacer en mi vida académica, - y algunas veces fuera de ella - es justamente buscar ser un jung Luhmannianer. La distinción entre alt y jung Luhmannianer tenía su origen en una diferencia que yo podía observar entre colegas y estudiantes en los años 2000, y que capturaba de manera provocadora la diferencia entre alt y jung Hegelianer en el debate marxista. Siempre me pareció un error interesarse en la teoría de Luhmann considerándola algo así como "una descripción de la sociedad moderna altamente abstracta y que mantenía una posición de observación apolítica y anormativa frente a los hechos". Varias veces escuché esta formulación de parte de profesores y de parte de estudiantes, especialmente de aquellos descolgados del marxismo que buscaban ahora un "pensamiento del Absoluto" (Spaemann) con el cual renovar su idea de totalidad. Esta formulación de la teoría 
de sistemas era también la misma que impulsaba Habermas y que hacía ver a Luhmann simplemente como un pensador conservador del siglo XX.

Quienes veían a Luhmann de este modo eran para mi alt Luhmannianer. La distinción no tiene que ver con una cuestión de edad, por supuesto, sino de comprensión de la teoría de sistemas. Los jung Luhmannianer son quienes pensamos que esa "descripción abstracta de la sociedad moderna" es - como lo dice Luhmann por cierto - comunicación en la sociedad. Somos quienes pensamos que no se puede describir la sociedad sin construirla y transformarla en la misma descripción; quienes pensamos que la norma es un producto de la sociedad de la cual no podemos escapar y que, por tanto, la diferencia no es entre descripción y normatividad, sino entre descripción y contingencia, o entre norma y cognición. Jung Luhmannianer somos, por tanto, quienes pensamos que hay una política sistémica que no está prefigurada normativamente, sino que se construye en la operación del sistema, por ella y, eventualmente, contra ella.

Viendo las cosas de este modo, jung Luhmannianer deben sentirse todos aquellos que asumen que la teoría de sistemas es una teoría de la diferencia, que es autológica, y cuyo pathos último no es, por supuesto, la defensa del sistema ni nada que se le parezca, sino la mantención de la apertura de posibilidades contingentes. Jung Luhmannianer es quien asuma que, a pesar de que podemos describir el funcionamiento de los sistemas, no hay ningún fundamento en la evolución de la sociedad para que esos sistemas existan y se mantengan tal como están; el impulso se lo dan ellos mismos. La contingencia es valor propio de la sociedad moderna. Un jung Luhmannianer tiene que sospechar cada vez que la comunicación de un sistema indique que algo es necesario o que su transformación es imposible. Ese tipo de comunicaciones es únicamente una formulación del sistema para sostener su propia necesidad; la misma que se disuelve en contingencia cuando la descripción muestra que, a falta de fundamento, la recursión es lo que cuenta.

En honor a la contingencia, confieso que puede ser mi sesgo, pero me parece que la mayor parte de los teóricos latinoamericanos de sistemas operan como jung Luhmannianer. Ya hay pocos que consideren que la teoría no se compromete políticamente, que es solo una herramienta de descripción, o que no tiene interés en la normatividad. Por supuesto la normatividad de la teoría de sistemas no puede encontrarse en la vinculación con el pesado legado kantiano, o con un comunitarismo neoaristotélico inadecuado a la época de Twitter, sino en la defensa de la contingencia de opciones ante los intentos sistémicos por ocultarla tras necesidades e imposibilidades que, en último término, tienen estatuto de invención. Esto es lo que veo en la mayor parte del pensamiento sistémico latinoamericano. Y si esto es cierto, entonces me parece que el balance entre los alt y los jung Luhmannianer es positivo para los jóvenes. 


\section{Acerca de las propuestas de la teoría de sistemas para la sociología de América Latina}

S\&A. ¿Cuál es, a su entender, el aporte que la perspectiva de sistemas podría hacer a la sociología de América Latina, entendida ésta como la sociología que se dedica a estudiar esta región, pero también como la sociología que se hace en la región?

A.M. El aporte de la teoría de sistemas a la sociología latinoamericana ya es claro: es la investigación de una región en términos de su proceso de diferenciación funcional y de cómo ese principio de diferenciación se interpenetra con las otras formas de diferenciación (estratificación, centro/periferia, segmentación) en la perspectiva de una sociedad mundial. Ninguna región del mundo hoy puede ser investigada con prescindencia de la existencia de una sociedad mundial.

De nuevo, para que quede totalmente claro, sociedad mundial es una unidad de diferencias. En tal sentido, estudiar América Latina, o cualquier región de la sociedad mundial, es estudiar la sociedad mundial, no por el solo hecho de que la región es parte de esa sociedad, sino porque aquello que acontece históricamente en la región no es comprensible sin el análisis de sistemas transnacionales y transregionales. Los efectos son complejos. La historia de la región no es entendible como historia latinoamericana, sino como historia global. Cuando la teoría de sistemas de América Latina estudia la circulación de conocimientos, los problemas socioecológicos, las transformaciones constitucionales, los procesos de diferenciación, hace un aporte a la historia y a la sociología global.

S\&A. Dentro del menú actual de perspectivas de investigación sobre América Latina, y en vistas de las que cuentan con mayor recorrido en nuestra región tanto como de aquellas otras más recientes, por caso la perspectiva post-colonial y sus variantes ¿Considera factible el diálogo de la teoría de sistemas sociales con estas u otras posturas concentradas en fenómenos regionales? Por cierto, dialogar no significa aquí establecer consensos, sino elaborar una agenda de temas comunes y profundizar conjuntamente su problematización. En caso afirmativo ¿Cuáles serían a su entender los ejes comunes más productivos para ese diálogo? En caso negativo ¿Cuáles serían las razones de la imposibilidad de elaborar una agenda común?

A.M. El diálogo de la teoría de sistemas con otras teorías es siempre posible, pero no creo que haya que desarrollar para ello una agenda común. Hay, en todo caso, ejes que permiten ese diálogo. Por ejemplo, cuando se analizan las relaciones entre regiones de la sociedad mundial, la teoría de la dependencia 
o la teoría de sistemas-mundo de Wallerstein son buenas candidatas históricas para el diálogo con la teoría de sistemas. O cuando se analizan las relaciones que permiten el despliegue de la diferenciación funcional a nivel global, las teorías postcoloniales y decoloniales son otras candidatas. El grupo Desigualdades de Sergio Costa en Berlín, la perspectiva plural de inspiración marxista de José Mauricio Domingues y la crítica a la modernización de Kathya Araujo me parecen muy interesantes para este vínculo, por ejemplo. O cuando queremos conocer las particularidades históricas de regiones nacionales o transnacionales, la nueva historia de las prácticas sociopolíticas en América Latina (Ossa, Jaksic, Gallo, Breña, Quintero, Sábato, Ternavasio, entre otros) y la historia global son aliados imprescindibles.

A mi parecer, sin embargo, tiene que haber ciertas condiciones previas en las teorías y en los grupos que las practican para establecer este diálogo. Primero, las teorías deben tener una aproximación interdisciplinaria a sus temas de investigación. La teoría de sistemas es inmanentemente interdisciplinaria: biología, sistemas complejos, historia, evolución estructural y de las ideas, teoría de la comunicación, sociología, son sus componentes fundamentales. En tal sentido, la teoría de sistemas es una teoría abierta que está en muy buen pie para emprender distintos tipos de diálogo, incluso con teorías no sociales, como la evolución biológica, la ingeniería de sistemas complejos, las teorías ecológicas. La pregunta es si otras teorías sociales están en condiciones de entablar este diálogo, o si están políticamente cooptadas por alguna opción que le atribuye a la teoría de sistemas una "intencionalidad política" determinada.

Segundo, y en relación con lo anterior, me parece que para que exista un diálogo entre teorías, los grupos que las llevan adelante deben estar desprovistos de cualquier forma de dogmatismo. Esta ausencia de dogmatismo no la veo en las teorías marxistas en general, que siguen insistiendo en que la distinción capital/trabajo es la clave interpretativa de la sociedad del siglo XXI. Tampoco la veo en el postcolonialismo, el cual no puede salirse de la distinción entre centro opresor y periferia oprimida, ni en la aproximación habermasiana, que sigue pensando en que hay un mundo mejor después del consenso, como si el universo se detuviera ahí.

Los nexos con otras teorías generales me parecen un ejercicio puramente de compabilización conceptual, como el que desarrolla Armin Nassehi con la teoría de campos de Bourdieu. Una excepción es el trabajo en la intersección de Luhmann y Latour que ha llevado adelante Ignacio Farías en Alemania, aquí hay aún mucho que explorar; o el de Niels Akerstrom Andersen con Luhmann y Foucault en problemas de governance y teoría general de las organizaciones modernas.

En mi propia experiencia de los últimos cinco años investigando procesos de crisis social, me parece que quienes están más abiertos a un diálogo interteórico - y deseosos de él - son las teorías no sociales, como la teoría de 
sistemas dinámicos complejos o las teorías ecológicas. Estas aportan al diálogo un background teórico extenso y profundo que se remonta hasta la teoría de las catástrofes de René Thom y que alcanza a la reciente teoría de las transiciones críticas en sistemas complejos de Scheffer. Por otro lado, estas teorías son universales en el sentido que se aplican también al ámbito físico y natural, además del social, y ofrecen algo que a la teoría de sistemas de Luhmann le ha faltado desde sus inicios: una metodología acorde con sus premisas teóricas, basada en teoría de grafos, de modelamiento de sistemas dinámicos o de modelamiento de agentes. Especialmente en una época de big data y de entrelazamientos cada vez más complejos entre sociedad, tecnología y mundo físiconatural, la conexión con estas teorías y campos de análisis es central para renovar las aproximaciones interdisciplinarias y para expandir la teoría de sistemas más allá del uso de fuentes históricas y cualitativas.

En tercer lugar, otra condición para el diálogo interteórico es un requerimiento que va más allá de la inclinación por una aproximación interdisciplinar y la ausencia de dogmatismo en los círculos científicos con los que se pretenda dialogar. Se trata de una condición sistémica que en América Latina está subdesarrollada. Me refiero al financiamiento de fondos genuinamente interdisciplinares que puedan sostener una investigación científica de este tipo en el tiempo. Por investigación interdisciplinar no me refiero al simple diálogo entre disciplinas afines como sociología y politología, por ejemplo. Me refiero, más bien, a la vinculación de una socióloga de sistemas con una ingeniera de sistemas, o de un sociólogo de sistemas con físicos, matemáticos y ecólogos. Esto puede resolverse a nivel de temas, focos de investigación, teorías generales y complementaciones metodológicas.

Para este tipo de interdisciplinariedad, que es la que a mi juicio mayores rendimientos teóricos, metodológicos, cognitivos y aplicados reporta, las condiciones del sistema científico latinoamericano son subcomplejas. Aún persiste institucionalmente una separación entre ciencias sociales y naturales que hace difícil dedicar fondos y tiempo a estos esfuerzos mayores. Y más aún, subsisten criterios de evaluación unilaterales que no motivan a la investigación interdisciplinar; fondos por disciplinas, esquemas de productividad diferenciados, paneles de evaluación "interdisciplinarios" en los que cada evaluador juzga desde su disciplina sin capacidad de observar el aporte de las demás a un resultado emergente, exigencias de tiempos equivalentes para esfuerzos interdisciplinares complejos y para investigaciones unidisciplinares, entre otros. Con ello, no hay mayores incentivos al diálogo interdisciplinar serio, de largo aliento, como todo esfuerzo científico verdadero requiere.

Solo basta imaginarse cuántos rendimientos obtendríamos de este diálogo de la sociología sistémica con otras áreas del conocimiento a distintos niveles, rendimientos de alta relevancia para la governance de América Latina y que interesan especialmente a las políticas nacionales. Primero, rendimientos 
en conocimiento original para la producción científica global; segundo, rendimientos en áreas clásicas de policy making como el desarrollo de medicamentos, procedimientos educativos, la construcción de infraestructura básica y de segunda generación, organización urbana; tercero, rendimientos en áreas hoy cruciales como el cambio climático, sus impactos y su management en las diversas zonas socioecológicas de América Latina; y cuarto, rendimientos en la preparación para enfrentar los crecientes problemas sociotécnicos en áreas urbanas, en el ámbito del trabajo, en el de la medicina, en el de los transgénicos, en el de las tecnologías de comunicación.

Por más que me esfuerzo, no veo a las teorías postcoloniales ni decoloniales aportando en esto una visión sociológica. Tampoco al marxismo, a la teoría de la acción comunicativa o a la teoría de Bourdieu. Seguramente, sin dejar de crear conocimiento para sus campos, prima en ellas fundamentalmente la operación de segundo orden de la crítica. Y a pesar de que todas compartirían la unidad de teoría y praxis, no se ensucian las manos con las operaciones de primer orden de la sociedad moderna. La teoría de sistemas, en cambio, está hecha a la medida de esta doble exigencia, como observación de segundo orden que produce conocimiento, y como teoría de la intervención de primer orden en los sistemas sociales de la sociedad moderna.

S\&A. La TdSS se caracteriza por una pretensión de generalidad teórica que, a primera vista, se ubica arriba de las experiencias históricas específicas. Como se sabe, hay una larga tradición teórica en América Latina que propone que la tensión entre teoría y historia es decisiva para la creatividad teórica en la región ¿Cómo ayudaría la TdSS a reubicar ese problema?

A.M. Cualquier teoría se ubica por sobre experiencias históricas específicas. Por eso se trata de teorías y, especialmente, de teorías generales. Pero el problema no es dónde se ubica la teoría, sino cómo ella es construida. Si lo es desde la unidad o desde la diferencia.

Las teorías de la unidad son generalmente modelos que arrancan de una premisa normativa que se da por sentada - petitio principii -, que no se pone en discusión. La construcción de teoría en estos casos es para "demostrar" la necesidad del principio seleccionado. Ejemplos de esto son la teoría de Habermas, cualquier forma de marxismo y de filosofía de la historia y la economía clásica, entre otras. Las teorías de la diferencia, en cambio, parten de una diferencia a la que subyace una paradoja, y la despliegan para mostrar justamente cómo el mundo se esfuerza por ocultar esa paradoja mediante complejas construcciones sociales históricas. El resultado es que no hay principio que fundamente lo social, sino solo paradojas que le dan vida. La construcción de teoría en estos casos muestra la forma en que el mundo se comporta para llenar el vacío de su incompletitud última. Ejemplos aquí son la teoría de Jacques Derrida, la 
transitividad latouriana, el emergentismo de Archer (cuando se lo despoja del fundamento de la persona humana), y por cierto la teoría de sistemas de Niklas Luhmann.

Las teorías de la unidad usan la historia para ordenarla de forma tal que el movimiento histórico sea la constatación del principio normativo que está en la base de la teoría. Un ejemplo de esto es la teoría de la diferenciación de sistema y mundo de vida de Habermas. Después de reconstruir la historia de este modo, no queda otra opción que pensar en la ética del discurso como única solución a la "colonización del mundo de la vida". Otros ejemplos similares en su forma son las filosofías de la historia como la kantiana, o los modelos histórico-culturales como los de Spengler o Toynbee.

Las teorías de la diferencia, en cambio, arrancan de la historia y observan cómo se despliega en ella justamente la diferencia. Esto es justamente lo que hace Niklas Luhmann. Es cierto que Sistemas sociales es un libro de teoría general, pero ningún otro libro de Luhmann lo es. Incluso La sociedad de la sociedad es un libro profundamente histórico en sus cuatro subteorías: la de los medios de comunicación - de difusión y simbólicamente generalizados -, la teoría de la evolución, la teoría de la diferenciación y la teoría de las autodescripciones. Me cuesta pensar en un libro de Luhmann que no sea un libro "de historia". Todas las monografías de sistemas sociales están plagadas de información histórica original en muchos casos.

La reconstrucción de los sistemas funcionalmente diferenciados no se hace a partir de un modelo analítico tipo AGIL, sino a partir de la historia. De esto resulta una teoría de sistemas profundamente historizada en la que: a) hay sistemas que se diferencian históricamente primero como la religión, la política, y la economía; y otros que lo hacen después, como el derecho, los medios de difusión, el arte, la ciencia; b) hay algunos sistemas que cuentan en su núcleo con medios de comunicación simbólicamente generalizados como el dinero en la economía y el poder en la política, y otros que no desarrollan históricamente medios muy precisos, como el arte, la religión o la educación; c) hay sistemas que tienen una doble codificación histórica como la economía: primero propiedad y luego dinero, y otros que funcionan prácticamente sin medio, justamente como los medios de difusión; d) hay sistemas que han ubicado a los individuos como referencia en su centro, como la educación o la intimidad, y otros en los que los individuos son un dato casi irrelevante en la operación sistémica, como la economía; e) hay sistemas que históricamente se diferencian de manera fuerte en codificación, programación y medio, como la ciencia, y otros que operan desde sus inicios en términos de una comunicación flotante, como la moral; f) hay semánticas que se acoplan históricamente de un modo indisociable al sistema, como la semántica del Estado con la política y del mercado con la economía, y otras que se acoplan de manera débil a varios, como la semántica de la justicia. La lista se puede continuar indefinidamente. 
¿Alguien puede pensar solo después de esto que la teoría de sistemas no es a la vez historia?

Lo que hace Luhmann en Sistemas sociales es abstraer los resultados de sus análisis históricos de los que ya había hecho en política, religión, ciencia, derecho, intimidad, moral, educación, arte, economía, y de los que seguía haciendo en estos campos. Si alguien piensa que por ello la teoría de sistemas es ahistórica es o porque leyó Sistemas sociales en diagonal, o porque simplemente no es capaz de leer observaciones de segundo orden.

Este mismo modelo luhmanniano de continuo diálogo entre teoría e historia es el que siguen todos los teóricos de sistemas de América Latina que he mencionado más arriba. Si no lo hicieran, si no lo hiciéramos, no existiría algo reconocible como una teoría de sistemas de América Latina. No existiría este número especial ni esta entrevista. Para la teoría de sistemas es la historia de la sociedad la que manda, no la teoría. Así sucede con las teorías de la diferencia.

\section{Acerca del concepto de región de la sociedad mundial}

S\&A. ¿Considera que América Latina puede ser tratada como una región de la sociedad mundial? ¿Cuál sería el nivel operativo del concepto de región en relación con los sistemas funcionales y en relación con el concepto de sociedad mundial?

A.M. Esta pregunta me parece crucial para el análisis sistémico contemporáneo. Creo que yo mismo en mis escritos no la he podido resolver satisfactoriamente. Intentaré hacerlo en esta ocasión.

Sobre la base de la inmanencia de la historia en la teoría de sistemas que he mencionado más arriba, una primera consideración es que las regiones tienen límites históricos de sentido. Creo que es un error entender que, por ejemplo, la región América Latina es un espacio meramente geográfico y que como tal - o porque tal - debe ser considerado sin más una región de la sociedad mundial. La denominación América Latina emerge en el siglo XX como autodescripción en la comunicación, y cuando una autodescripción es recursiva en la comunicación, la comunicación de los sistemas comienza a referir a ella en estos términos y a orientar sus operaciones según esta autodescripción. Esto puede coincidir o no con límites geográficos, pero siempre coincidirá con denominaciones históricas de sentido.

Si América Latina es una denominación en la comunicación a la que los sistemas pueden referir y si esta denominación gana en redundancia, una segunda consideración entonces, es que resulta difícil abstraerse en términos operacionales de la identidad regional que se forma. Esto hace que en múltiples comunicaciones la referencia sea América Latina. Solo a modo de ejemplo, en 
el siglo XIX se habló de la "barbarie" americana, para diferenciarla de los modos de vida "civilizados" que se desarrollaban en las incipientes áreas urbanas y que reproducían estilos de vida europeos. En el siglo XX se habló del subdesarrollo latinoamericano (Prebisch), o de la dependencia de la región respecto de centros europeos y americanos (Cardoso \& Faletto), o de América Latina como una zona de modernización caracterizada por asincronías y democracias con participación limitada (Germani). En el siglo XXI se habla de un "nuevo constitucionalismo latinoamericano" que parece recoger en términos constitucionales (transconstitucionales) muchas de las exclusiones históricas presentes en la región.

Todas estas autodescripciones de la región sin duda tuvieron y tienen efectos en la operación de sistemas. La política buscó a tal punto la civilización de la barbarie que el genocidio de pueblos indígenas y la eliminación de sus tradiciones se consideró una tarea estatal nacional en varios o todos los países de la región. La economía se orientó a tal punto a la superación del subdesarrollo en el siglo XX que creó, en acoplamiento con la política, uno de los programas más ambiciosos de independencia económica regional de que se tenga registro en la historia global: la industrialización sustitutiva de importaciones.

Y el derecho hoy, también en acoplamiento con la política, parece tener un programa regional que busca expiar las culpas del pasado latinoamericano incluyendo todo tipo de derechos en el nivel constitucional, como si esta inflación de compromisos de valor restituyera expectativas normativas de los actores muertos, y como si ella no fuese a transformarse en el futuro en una deflación que llevará a la región a autoritarismos y democracias iliberales, como ya se puede advertir en los casos de Venezuela y Bolivia. Es decir, el éxito de la autodescripción regional América Latina efectivamente implica operaciones en distintos sistemas sociales, con consecuencias históricas claras en lo que ya ha acontecido, y con consecuencias futuras impredecibles en lo que está por venir.

Una tercera consideración de América Latina como región de la sociedad mundial tiene que ver con la confirmación sistémica de las distinciones. América Latina se reafirma como tal en las operaciones políticas, en cada encuentro regional, en distintos foros internacionales, en cada reunión de empresarios regionales, en sociedades científicas de distinto tipo de alcance regional (no solo en los encuentros de intelectuales sistémicos), en operaciones religiosas referidas a la organización de la "iglesia latinoamericana" (cualquiera sea su denominación), en operaciones jurídicas como las de la Corte Interamericana de Derechos Humanos, en operaciones económicas como las de Mercosur. En todas estas operaciones sistémicas América Latina puede no significar exactamente lo mismo, pero esa es justamente la gracia de la comunicación sistémica de sentido: que no precisa de literalidad, sino del pragmatismo de la aceptación - o el rechazo - de la comunicación para continuar con ella. 
Una cuarta consideración es un argumento que tomo directamente de Luhmann en La sociedad de la sociedad. Este se asocia a la forma en que interactúan los principios de diferenciación en la sociedad moderna. Sin diferenciación funcional no hay posibilidad siquiera de pensar en una sociedad mundial, pero ella tampoco es comprensible en un sentido histórico únicamente como diferenciación funcional. Esto sería dogmatismo sistémico (alt Luhmannianer). Los principios de segmentación centro/periferia y estratificación, se acoplan de modos distintos. Sus formas de acoplamiento emergen y cambian históricamente y dan origen a la denominación y operación de regiones, en las que no solo la región implicada se reconoce a sí misma y remite sus comunicaciones, sino que es reconocida también por otras regiones en las que acontece lo mismo de otro modo.

Luhmann argumenta esto en relación a cómo los centros de la sociedad mundial, típicamente centros urbanos que adensan operaciones funcionales, producen fluctuaciones a las cuales luego las periferias (incluidos otros centros) tienen que adaptarse por medio de autoorganización. Esto genera segmentación en regiones, por ejemplo, para locación de capitales en la economía, regiones donde es más rentable invertir o donde determinados empleos muestran ventajas comparativas; para el desarrollo de reacciones fundamentalistas a procesos de secularización en la religión, como Medio Oriente; para el surgimiento de poderes regionales ante el derrumbe de poderes mundiales, como aconteció con la disolución de la Unión Soviética; para la especialización de la investigación científica en distintas zonas socioecológicas del globo, como acontece con la ciencia antártica, investigación subsahárica, ciencia amazónica, investigación astronómica en zonas de cielos claros, entre otros.

Todo ello indica que la región América Latina es una región entre otras de la sociedad mundial. Es una distinción segmentaria con consecuencias operativas para el funcionamiento de los sistemas, tal como lo son, incluso con mayor fuerza, los Estados nacionales.

S\&A. Dada la importancia de la diferenciación segmentaria de Estados nacionales en el marco del sistema político mundial ¿Cómo deberían tratarse los Estados nacionales desde una perspectiva sistémica para América Latina?

A.M. El sistema político de la sociedad mundial opera funcionalmente por medio de la codificación del poder y de la implementación de programas políticos, pero se autoorganiza a través de la distinción segmentaria de Estados nacionales y, como lo he afirmado recién, también por la distinción segmentaria de regiones de la sociedad mundial. Aunque esta aún no alcanza el nivel de especificación político-jurídico que han logrado los Estados nacionales desde Westfalia en la región europea, desde los procesos de independencia del siglo XIX en la región latinoamericana. 
Este modo de funcionamiento no es distinto en América Latina. En algunos momentos históricos los Estados nacionales latinoamericanos parecen haberse encontrado en una mayor sintonía ideológica, por ejemplo, con gobiernos populares a fines de los años I960 e inicios de la década de I970; en otros han manifestado mayor antagonismo entre ellos como en la época de gobiernos militares; o incluso indiferencia, como en la época del auge de modelos neoliberales. Sin embargo, no creo que haya que medir las relaciones entre Estados nacionales en América Latina únicamente por la ideología política de sus gobiernos eventuales, ni por las declaraciones de amistad o antagonismo que se expresen en la esfera pública o en foros internacionales - aunque insultarse mutuamente es una de las pocas cosas que los gobernantes aún pueden manejar con cierta autonomía.

Los Estados nacionales operan en una relación de cooperación y competencia que es típica de las regiones emergentes de la sociedad mundial. Cooperación por medio de tratados y acuerdos internacionales y competencia a través de los mismos. Cooperación en cuestiones económicas y de seguridad de fronteras especialmente, y competencia por la atracción de inversiones, actividades comerciales, turismo y oportunidades de negocios. Los Estados tienen siempre esta tensión entre autonomía e interdependencia: la autonomía contribuye a su reafirmación como Estados frente a otros segmentos iguales, y la interdependencia colabora en la formación y operación de la región. Esta es materia preferida de politólogos y la teoría de sistemas haría bien en acercarse a estas investigaciones, a veces áridas, para reconstruir sistémicamente una observación más global de los regímenes de governance de los Estados latinoamericanos.

Lo que me parece más interesante de investigar desde el punto de vista de la teoría de sistemas son las transformaciones del Estado latinoamericano en el siglo XX. Me refiero a tres momentos particulares: el desarrollismo (populista o democráticamente guiado), el Estado burocrático autoritario (O’Donnell) de los regímenes militares, y la versión latinoamericana del Estado mínimo en los regímenes neoliberales. En términos de historia de la sociedad mundial estas fases se corresponden con la crisis económica de I929 (inicio de fase desarrollista), con el auge de la Guerra Fría (fase burocrático-autoritaria) y con la posterior reacción a ella (fase neoliberal).

Habla también a favor de la construcción de una región latinoamericana el hecho de que los Estados de la zona hayan pasado por estas fases más o menos paralelamente. En cada caso hay operaciones estructurales y semánticas que hacen oscilar la región entre distintos atractores, y que organizan las relaciones de cooperación y competencia, de autonomía e interdependencia de modos distintos.

Cabe preguntarse, por supuesto, si con la crisis del modelo neoliberal (soluciones privadas a problemas públicos) y la expansión del denominado 
nuevo constitucionalismo, los Estados latinoamericanos entran en una nueva fase con particularidades operativas y semánticas compartidas. Este parece ser el caso. Se trataría de una fase en la que en términos de sociedad mundial se enfrenta una crisis generalizada de la democracia representativa. Una época en la que hay más derechos a disposición de los individuos por el éxito de la semántica de derechos humanos en la segunda mitad del siglo XX, pero también en la que, por las mismas razones, las trasgresiones a esos derechos y el incumplimiento de ellos (en términos de expectativas normativas) se hacen más visibles no solo para los afectados, sino para todos quienes observan en distintas regiones de la sociedad mundial.

El despliegue y desenlace de esto está por verse, pero desde Parsons en adelante sabemos que los procesos inflacionarios de compromisos de valor como los del nuevo constitucionalismo latinoamericano regularmente derivan en deflación de los mismos y en absolutismo de valores, es decir, en la imposición de determinadas construcciones normativas por medio de mecanismos coercitivos guiados desde el Estado por una política autoritaria o, al menos, iliberal, que limita drásticamente el pluralismo de valores. Rusia ha seguido esta trayectoria en la actualidad. Ningún país latinoamericano alcanza aún este nivel de "perfección", pero Venezuela y Bolivia han hecho lo imposible por acercarse. Está por verse el decantamiento de la situación democrática en Brasil y también en Chile en las próximas décadas.

S\&A. Su concepto de desdiferenciación ¿es parte de la teoría o de la metodología de la teoría de la sociedad? ¿Lo considera un concepto relativo a sistemas o a medios? ¿Ha explorado articulaciones entre su propuesta y otras versiones del concepto de desdiferenciación? ¿Considera factible una articulación del concepto de desdiferenciación con el concepto de clase social, y con cuál de las variantes de este último considera que habría más afinidad y/o con cuál menos afinidad? ¿Considera que los fenómenos de desdiferenciación tienen especificidades regionales, por ejemplo, estos fenómenos se dan de una manera en América Latina y de otra en diferentes regiones de la sociedad mundial?

A.M. Aunque no es empleado sistemáticamente en la construcción teórica, el concepto de desdiferenciación es de Niklas Luhmann. En Grundrechte als Institution (Los derechos fundamentales como institución, original de I965), Luhmann lo emplea para dar cuenta de la función de los derechos fundamentales. Los derechos fundamentales constituyen una limitación a la concentración de poder en la burocracia estatal y a los riesgos de desdiferenciación que ello implica para los otros sistemas sociales. Su función es evitar la politización (desdiferenciación) de la sociedad de manera tal de proteger a los individuos para que ellos dispongan de garantías de libertad comunicativa y suficiente motivación frente a comunicaciones de otros sistemas sociales además de la polí- 
tica. El concepto es empleado también en La sociedad de la sociedad, pero en sentidos y argumentos marginales.

Ha sido mi pretensión - es decir, así lo he intentado - introducir el concepto de desdiferenciación en el nivel de la teoría a la misma altura de los conceptos de acoplamiento estructural e interpenetración. Para esto había que darle al concepto un estatuto teórico. Mientras que el acoplamiento estructural supone un préstamo de complejidad entre sistemas - la Constitución es el caso prototípico -, y la interpenetración queda reservada para la relación de conciencia y sociedad por medio de la comunicación, entendí la desdiferenciación como un evento en el que la operación de un sistema utiliza elementos de la complejidad de otro unilateralmente (una red de ellos generalmente) para reproducir su propia complejidad, impidiendo al sistema afectado emplear esa red de elementos en operaciones propias. Esta es una definición altamente abstracta que tiene una base histórica.

Los sistemas más proclives a poner en movimiento eventos de desdiferenciación son los que evolutivamente han acoplado de manera estricta operación sistémica y medio simbólico, especialmente la política y la economía. En el primer caso se puede hablar de politización, en el segundo de monetarización. Los Estados totalitarios del siglo XX, como la Alemania nazi y la Unión Soviética, y con menor intensidad el Estado desarrollista latinoamericano, es pecialmente en su versión populista, y el Estado burocrático-autoritario fueron altamente proclives a la politización de la sociedad. Establecieron criterios políticos en la economía, en la educación, en la ciencia, en los medios, en el arte que impidieron a estos sistemas desplegar con autonomía su propia autopoiesis. No es que estos sistemas no pudieran funcionar con criterios propios, sino que debían responder a ciertos estándares (finalidades, objetivos) definidos políticamente que les impedían el empleo pleno de su potencial operativo. Estos estándares servían fundamentalmente a la reproducción de la complejidad política: fijación de precios, diseño e implementación de programas educativos y científicos ideológicamente orientados, propaganda en los medios, promoción de ideales políticos en el arte, entre otros.

La monetarización, por su parte, es propia de los ordenamientos denominados neoliberales. El ejemplo extremo es el caso de Chile, donde el Estado autoritario, como reacción a la politización de las décadas de i 960 e inicios de I970, cede su capacidad de coordinación del orden social a las operaciones económicas, al mercado. La desdiferenciación se produce aquí especialmente por la monetarización de los servicios sociales, de la salud, de la educación básica y superior, de las pensiones, del transporte, y de los servicios básicos como agua y electricidad. Se controla con ello el acceso al sistema privado y se indexa la calidad y oportunidad de los rendimientos al pago monetario. Nuevamente, no es que los sistemas funcionales no tengan capacidad de operación, pero quedan supeditados al metacódigo privado/público, donde lo privado se 
ejerce en relación al pago y lo público, siempre mayoritario, queda circunscrito a operaciones de baja calidad y tiempos de espera indefinidos especialmente en el ámbito de la salud.

No solo la política y la economía pueden mantener eventos de desdiferenciación prolongados, otros sistemas con alta integración de codificación y medio simbólico también pueden realizarlo. La judicialización, por ejemplo, consiste en una inflación de las operaciones jurídicas para resolver problemas políticos. Los Estados de bienestar europeos en particular, han experimentado estas formas de desdiferenciación que inmovilizan las operaciones funcionales porque el sistema jurídico no da abasto para resolver problemas que requieren decisiones políticas o económicas autónomas. A esto se le ha llamado euroesclerosis.

Algo similar puede acontecer con eventos de desdiferenciación de la ciencia sobre la política: la decisión puramente técnica de cuestiones que requieren una profunda consideración política por sus consecuencias eventuales cuenta como una desdiferenciación de operaciones políticas por parte de operaciones científicas. Sin ir más lejos, las revueltas políticas de los últimos años en Brasil, Ecuador y Chile se iniciaron por alzas en el transporte público decididas por paneles o estándares técnicos que no consideraron las posibles consecuencias políticas. Por cierto, no basta un alza en el transporte público para incubar una crisis, pero sí basta para desatarla cuando cae como último grano de arena en un sistema críticamente autoorganizado.

Una de las consecuencias más relevantes de los eventos de desdiferenciación es su acumulación en espacios regionales a distinto nivel. Puesto que las desdiferenciaciones quiebran las barreras de convertibilidad entre sistemas, es decir, impiden el funcionamiento de límites de contención a los efectos de rebalse (límites de contención como planes de garantías explícitas de atención en salud, disposiciones legales o constitucionales por el derecho a la educación o pensiones dignas, prevenciones morales de trato igualitario, ideales políticos de justicia y solidaridad), ellas producen acumulaciones sistemáticas de inclusión y exclusión frente a las que los sistemas funcionales afectados por los procesos de desdiferenciación difícilmente pueden reaccionar.

Como lo ha anticipado Luhmann en una de sus pocas predicciones acerca del futuro de la sociedad mundial, esto forma - muchas veces inadvertidamente, pero de modo recursivo - zonas de inclusión y zonas de exclusión a nivel subnacional, nacional, regional y global. La operación es la misma en todas las regiones, pero, por condiciones históricas, cada región experimenta las acumulaciones de inclusión y exclusión de modos diversos, aunque comparables. En las zonas de inclusión, el acceso, calidad y oportunidad de los rendimientos son aceptables para la mayoría de la población; en las zonas de exclusión el acceso, calidad y oportunidad tienen lugar de forma precaria, de modo que el rendimiento de sistemas funcionales es insuficiente para repro- 
ducir las necesidades sociales y en muchos casos biopsicológicas de las personas. Marcelo Neves ha llamado a estos grupos subincluidos: tienen deberes, pero no derechos.

Creo que, si algún rendimiento puede tener hoy el concepto de clase social en conexión con el concepto de desdiferenciación en el marco de la teoría de sistemas sociales, es justamente en la observación de los distintos tipos de inclusión y exclusión que la desdiferenciación de sistemas - y la indiferencia de la diferenciación - produce a diversos niveles regionales. Por supuesto, no solo en América Latina, sino en distintas regiones del globo.

La inclusión y la exclusión no son dos estados en equilibrio. Lo interesante de trabajar con distinciones es que siempre se puede hacer una re-entry de la distinción en la distinción, justamente para captar las sutilezas empíricas y las paradojas con las que opera la diferencia entre inclusión y exclusión en vida real. Eso abre la distinción a muchas variantes de alcance universal. Por ejemplo: a) inclusión en la exclusión, es decir, operar en una situación de inclusión dependiente de condiciones ilegítimas, como los círculos de redes de narcotráfico que tienen acceso a rendimientos (inclusión) bajo condiciones ilegales (exclusión); b) exclusión en la inclusión, esto es tener un acceso limitado a rendimientos frente a los cuales otros tienen un acceso mayor, por ejemplo, por razones monetarias o en base a preferencias políticas; c) autoexclusión y autoinclusión, una decisión, de la mayor autonomía y reflexividad individual, de excluirse de determinados rendimientos sociales, por ejemplo, no asistir a la iglesia, o de incluirse en ellos cuando las condiciones lo hagan aconsejable, por ejemplo, participar de elecciones políticas en casos donde se sienta que algo se juega; d) inclusión por riesgo e inclusión por peligro, una situación que generalmente tiene lugar en contextos de decisiones organizacionales o de funcionamiento de tecnologías complejas; en ellas quien toma la decisión se autoincluye en una situación riesgosa, pero quien no participa de la decisión y es afectado por las potenciales consecuencias queda incluido bajo condiciones de peligro y, a la vez, excluido del proceso decisional; e) inclusión compensatoria, estas son regularmente las transferencias y servicios del Estado a la población de menores recursos para que superen la línea de pobreza; se trata de una inclusión precaria, pero legítima que se debe distinguir de la inclusión en la exclusión; y f) la mencionada subinclusión, es decir, la exigencia de deberes estatales, pero sin la posibilidad de ejercer derechos de todo ciudadano; esta regularmente ocurre en zonas de exclusión desde donde el Estado se ha retirado como presencia operativa y simbólica y ha cedido su espacio a grupos que monopolizan el uso de la violencia (como redes de narcotráfico, delincuencia o crimen organizado).

¿Pueden ser estas distintas formas de inclusión y exclusión las "nuevas" clases sociales de la diferenciación funcional? Si el concepto de clase social es desprovisto de su carga semántica asociada a la distinción capital/trabajo pue- 
de ser, pero no alcanzo a ver, seguramente por mi propia ceguera sistémica, por qué esto habría de ser teórica, analítica, o incluso empíricamente necesario. El concepto de clase social presupone la existencia de una sociedad estratificada en la que el problema principal es la explotación. La distinción inclusión/exclusión, por su parte, presupone la operación de sistemas funcionales transnacionales en un contexto de sociedad mundial, y si esto es así, entonces el problema principal ya no es la explotación, sino la indiferencia de (todos) los sistemas sociales en relación a qué persona se incluye o es excluida de los rendimientos funcionales.

Esto no significa que las clases sociales dejen de existir por el simple hecho de aplicar otra distinción. Pero si con esa otra distinción se observa un problema más fundamental - el de la indiferencia de la diferenciación funcional -, es teóricamente parcial y políticamente irresponsable no advertirlo y seguir operando como si un grupo de capitalistas organizados oprimiera a trabajadores indefensos bajo las condiciones de un capitalismo salvaje del siglo XIX. Las formas de opresión actuales son mucho más sutiles, complejas y poderosas que eso. Operan naturalizando necesidades e imposibilidades, es decir, eliminando contingencia. Por cierto, las condiciones de explotación siguen existiendo en sweatshops y constelaciones similares, especialmente, y aunque no solo allí, en la región asiática, pero la verdadera revolución mundial emancipatoria de hoy tendría que ser contra la diferenciación funcional y no contra el capital. ¿Pero quién la haría?

En el siglo XX la indiferencia también cautivó a los trabajadores. Por muy "poderosos" que parezcan los capitalistas y por muy "poderosos" que parezcan los trabajadores cuando se "organizan", el poder es un medio simbólicamente generalizado que ni ellos ni nadie puede capturar en su totalidad, aunque, como lo he dicho, la desdiferenciación crea las condiciones para creer que esto sería posible. 
Sergio Pignuoli Ocampo es doctor en ciencias sociales de la Universidad de Buenos Aires. Actualmente se desempeña como investigador de carrera del Consejo Nacional de Investigaciones Científicas y Técnicas con sede en el Instituto de Investigaciones Gino Germani y como docente regular de la cátedra "Niklas Luhmann y la sociología de la modernidad". Desarrolla investigación en teoría sociológica, teoría y epistemología de sistemas sociales y teoría de la comunicación y es investigador responsable del PICT 20I5-007I: "La tensión entre diadismo y dualismo en las teorías sociológicas contemporáneas. Un estudio sistemático de los programas de Luhmann, Latour, Habermas, Schütz, Garfinkel, Giddens y Archer", financiado por BID y ANPCyT.

Antonio Brasil Jr. é professor adjunto do Departamento de Sociologia e do Programa de Pós-Graduação em Sociologia e Antropologia da Universidade Federal do Rio de Janeiro. Editor de Sociologia \& Antropologia. Jovem Cientista do Nosso Estado (JCNE/Faperj). É autor de Passagens para a teoria sociológica (2013). 


\section{NOTAS}

I A escolha da base SciELO se deveu a duplo critério. De um lado, sua capilaridade na América Latina, incorporando grande parte de suas revistas qualificadas; de outro, a existência de metadados estruturados e passíveis de manipulação por meio de ferramentas computacionais. Vale lembrar, no entanto, que essa base é seletiva em seu regime de indexação e, portanto, não nos traz uma imagem exaustiva da produção científica da região. Registre-se, por exemplo, a ausência da Revista MAD (Revista del Magíster en Análisis Sistémico Aplicado a la Sociedad), central na reflexão sobre o programa sistêmico na América Latina.

2 Trata-se de um projeto levado a cabo por Lucas Carvalho (UFF) e Antonio Brasil Jr. (UFRJ), cujos resultados preliminares ainda não foram publicados.

3 Sua tese foi publicada posteriormente na Alemanha: Souto, Cláudio. Allgemeinste wissenschaftliche Grundlagen des Sozialen. Wiesbaden: Franz Steiner, I984.

4 Villas Bôas Filho, Orlando. Teoria dos sistemas e direito brasileiro. São Paulo: Saraiva, 2009; Bachur, João Paulo. Às portas do labirinto: para uma recepção crítica da teoria social de Niklas Luhmann. São Paulo: Azougue, 201o; Palma, Maurício. Technocracy and selectivity: NGOs, the UN Security Council and Human Rights. Baden-Baden: Nomos; Holmes, Pablo. Verfassungsevolution in der Weltgesellschaft: Differenzierungsprobleme des Rechts und der Politik im Zeitalter der Globalen Governance. Baden-Baden: Nomos, 2013.

5 Portela, Fábio. Constitution: the evolution of a darwinian societal structure. Baden-Baden: Nomos, 2020 [no prelo].

6 Neves, Marcelo. "Systemtheorie"; "Evolution", "Systeme und Lebenswelt". In: Habermas-Handbuch. Stuttgart/Weimar: Metzler, 2009, p. 6I-65, 3I5-3I7, 364-376.

7 Cf., a título ilustrativo, Luhmann, Niklas. Das Recht der Gesellschaft. Frankfurt am Main: Suhrkamp, I993, p. 25, 8I, I94 478-9, 584; Die Gesellschaft der Gesellschaft. Frankfurt am Main: Suhrkamp, I997, tomo I, p. I69; tomo 2, p. 632, 787, 806, 810; Die Politik der Gesellschaft, Frankfurt am Main: Suhrkamp, p. 356, 428, 458; "Inklusion und Exklusion". In: Luhmann, Niklas. Soziologische Aufklärung 6. Opladen: Westdeutscher Verlag, p. 237-264 (p. 26I); Habermas, Jürgen. 
Wahrheit und Rechtfertigung: Philosophische Aufsätze. Frankfurt am Main: Suhrkamp, I999, p. 229 [trad. bras.: Verdade e justificação: ensaios filosóficos, São Paulo: Loyola, 2004, p. 223]; Zur Verfassung Europas. Ein Essay. Berlin: Suhrkamp, 20II, p. 33; Müller, Friedrich. Demokratie in der Defensive, Berlin: Duncker \& Humblot, 200I, p. 28, 63, 66, 78; Wer ist das Volk? Berlin: Duncker \& Humblot, p. 44-45, 47, 50, 52 [trad. bras.: Quem é o povo? São Paulo: Max Limonad, I998, p. 88-89, 9I, 95, 99]; Teubner, Gunther; Fischer-Lescano, Andreas. Regime-Kollisionen. Frankfurt am Main: Suhrkamp, 2006, p. I09; Ladeur, Karl Heinz. Der Staat gegen di Gesellschaft, Tübingen: Mohr, 2007; Brunkhorst, Hauke. Solidarität. Frankfurt am Main: Suhrkamp, 2002, p. I09, I25-I27, I32, I35, I53, I55, I60, I65-I66, 200; Fischer-Lescano, Andreas. Globalverfassung. Frankfurt am Main: Velbrück Wissenschaft, 2005, p. 30, 50, 55, 59, I44, 273-274; Möllers, Christoph. Gewaltengliederung. Tübingen: Mohr Siebeck, 2005, p. 40, 56-57; Buckel, Sonja. Subjektivierung und Kohäsion. Frankfurt am Main: Velbrück, 2007, p. 37, 52, 62, 73, 228; Grimm, Dieter. "Integration durch Verfassung: Absichten und Aussichten im europäischen Konstitutionalisierungsprozess". Leviathan 32/4, 2004, p. 448-463 (p. 454); Peters, Anne. "Compensatory constitutionalism: the function and potential of fundamental international norms and structures". Leiden Journal of International Law I9, 2006, p. 579-6Io (p. 608); Hassemer, Winfried. "Das Symbolische am symbolischen Strafrecht”. In: Festschrift für Claus Roxin zum 70. Geburtstag am I5. Mai 200I. Org. por Bernd Schünemann. Berlin: de Gruyter, 200I, p. I00I-IoI9 (p. I003); Buckel, Sonja; Christensen, Ralf; Fischer-Lescano, Andreas (orgs.). Neue Theorien des Rechts. Stuttgart: Lucius \& Lucius, 2006, p. 20-2I; Brodocz, André. Die Symbolische Dimension der Verfassung. Wiesbaden: Westdeutscher Verlag, 2003, passim.

8 Neves, Marcelo. "Verfassung und Öffentlichkeit: Zwischen Systemdifferenzierung, Inklusion und Anerkennung". Der Staat, 47, 2008, p. 477-510 [versão brasileira: "A constituição e esfera pública: entre diferenciação sistêmica, inclusão e reconhecimento". In: Melo, Claudineu de; Benevides, Maria Victoria \& Bercovici, Gilberto (orgs.). Direitos humanos, democracia e república: homenagem a Fábio Konder Comparato. São Paulo: Quartier Latin, 2009, p. 653-688; também in: Dutra, Roberto \& Bachur, João Paulo (orgs.). Dossiê Nik- 
las Luhmann. Belo Horizonte: Editora UFMG, 2013, p. I05I47] [trad. ital.: "Costituzione e sfera pubblica: tra differenziazione sistemica, inclusione e riconoscimento". Sociologia e politiche sociali, I4/2, 20I I: Costituzioni societarie: politica e diritto oltre lo Stato. Org. por Riccardo Prandini e Gunther Teubner. Milano: Franco Angeli, p. 79-IIo].

9 Neves, Marcelo. "Posfácio à edição brasileira (20I8): Constitucionalismo periférico 26 anos depois". In: Constituição e direito na modernidade periférica: uma abordagem teórica $e$ uma intepretação do caso brasileiro. São Paulo: WMF Martins Fontes, 2018, p. 367-435 (378-389).

Io Neves, Marcelo. Transconstitucionalismo. São Paulo: WMF Marins Fontes, 2009 [trad. ingl.: Transconstitutionalism. Oxford: Hart, 20I3; trad. ital.: Transcostituzionalismo. Macerata: Quodlibet, 2020 (no prelo)]; "Transconstitutionalism". Encyclopedia of the philosophy of law and social philosophy. Berlin: Springer, 20I8; Zwischen Themis und Leviathan: Eine Schwierige Beziehung - Eine Rekonstruktion des demokratischen Rechtsstaats in Auseinandersetzung mit Luhmann und Habermas. Baden-Baden: Nomos, 2000 [versão brasileira: Entre Têmis e Leviatã: uma relação difícil: o Estado democrático de direito a partir e além de Luhmann e Habermas. 3 ed. São Paulo: WMF Martins Fontes, 20I 2; 2 ed. São Paulo: Martins Fontes, 2008; I ed. 2006]; "From consent to dissent: the democratic constitutional State beyond Habermas". In: Ungureanu, Camil; Günther, Klaus \& Joerges, Christian (orgs.). Jürgen Habermas, v. 2, Adelshot: Ashgate, 20II, p. 99-I32.

I I Capriglione, Laura; Takahashi, Fábio. "FGV demite e causa polêmica internacional: Dispensa do professor Marcelo Neves leva intelectuais como Juergen Habermas a assinar lista contra decisão". Folha de S. Paulo, I2 jan. 2006. Disponível em: <https://wwwi.folha.uol.com.br/fsp/cotidian/ffr 2012006r7.htm>; Erdelyi, Maria Fernanda. "Apoio Internacional. Acadêmicos querem reverter demissão de professor da FGV". Conjur, 6 jan. 2006. Disponível em: <https://www.conjur.com.br/2006-jan-06/academicos_reverter_demissao_professor_fgv>.

I2 Cf. <https://www.conjur.com.br/2013-out-o8/fundacao-ge tulio-vargas-reconhece-bom-desempenho-professor-marcelo-neves>.

I3 Luhmann, Niklas. "Zur Einführung”. In: Neves, Marcelo. Verfassung und Positivität des Rechts in der peripheren Moder- 
ne: Eine theoretische Betrachtung und eine Interpretation des Falls Brasilien. Berlin: Duncker \& Humblot, I992, p. I-4 [trad. bras.: "Prefácio à edição alemã". In: Neves, Marcelo. Constituição e direito na modernidade periférica: uma abordagem teórica e uma intepretação do caso brasileiro. São Paulo: WMF Martins Fontes, 20I8, p. XVII-XXII].

I4 Stichweh, Rudolf. "Inklusion/Exklusion, funktionale Differenzierung und die Theorie der Weltgesellschaft". Soziale Systeme: Zeitschrift für soziologische Theorie 3. Opladen: Leske + Budrich, p. 123-136 (p. 132).

I5 Cf., por exemplo, em sua obra tardia, Luhmann, Niklas. Die Gesellschaft der Gesellschaft, tomo 2, p. 743; Das Recht der Gesellschaft, p. 572.

I6 Luhmann, Niklas. Die Gesellschaft der Gesellschaft, tomo 2, p. 8Io.

I7 Luhmann, Niklas. Das Recht der Gesellschaft, p. 584-586.

I8 Droit et Société : Revue Internationale de Théorie du Droit et de Sociologie Juridique, II/I2 (I989), 47 (200I).

I9 Luhmann, Niklas. "Le droit comme système social" (trad. franc. de Michel van de Kerchove]. Droit et Société, II/I2, p. 53-66, espec. p. 56-57.

20 Niklas Luhmann. Soziale Systeme. Grundriß einer allgemeinen Theorie. Frankfurt: Suhrkamp, I984, p. 510-5II [trad. ital. de A. Febbrajo e R. Schmidt: Sistemi sociali. Fondamenti di una teoria generale. Bologna: il Mulino, p. 579-580].

2I Luhmann, Niklas. Das Recht der Gesellschaft, p. 69.

22 Luhmann, Niklas. Die Politik der Gesellschaft. Frankfurt am Main: Suhrkamp, 2000.

23 Luhmann, Niklas. Die Politik der Gesellschaft, p. 265.

24 Neves, Marcelo. Symbolische Konstitutionalisierung. Berlin: Duncker \& Humblot, I998, p. I53-I59. [versão brasileira: A constitucionalização simbólica. 3 ed. São Paulo: Martins Fontes, 20II, p. I9I-200].

25 Neves, Marcelo. "From transconstitutionalism to transdemocracy". European Law Journal, 3/5, 2017, p. 380-394.

26 Rodríguez Mansilla, Darío \& Torres Nafarrate, Javier. Introducción a la teoría de la sociedad de Niklas Luhmann. Ciudad de México: Herder/Universidad Iberoamericana, p. 437ss.

27 Ribeiro, Pedro Henrique. 'Luhmann ‘fora do lugar'? Como 
a 'condição periférica' da América Latina impulsionou deslocamentos na teoria dos sistemas". Revista Brasileira de Ciências Sociais, 28/83, 2013, p. I05-123.

28 Mascareño, Aldo A. Die Moderne Lateinamerikas. Weltgesellschaft, Region und funktionale Differenzierung. Bielefeld: transcript Verlag; p. 24, 75, I08-III, I36, I6I, I75, 203, 209; "Grenzen der Kontrolle: Institutionalisierung und Informalisierung des Raums. Das Beispiel Lateinamerika". In: Goeke, Pascal; Lippuner, Roland \& Wirths, Johannes (orgs.). Konstruktion und Kontrolle: Zur Raumordnung sozialer Systeme. Wiesbaden: Springer VS, 20I5, p. I45-I76 (p. I47I48); Mascareño, Aldo A. \& Carvajal, Fabiola. "The Different Faces of Inclusion and Exclusion". Cepal Review, II6, 20I5, p. I27-I4I (p. I38).

29 Mascareño, Aldo. "Grenzen der Kontrolle: Institutionalisierung und Informalisierung des Raums. Das Beispiel Lateinamerica”, p. I47-I48 (grifo meu). Cf. Neves, Marcelo. "Die Staaten im Zentrum und die Staaten and der Peripherie: Einige Probleme mit Niklas Luhmanns Auffassung von den Staaten der Weltgesellschaft". Soziale Systeme: Zeitschrift für Soziologische Theorie, I2/2, 2006, p. 247-273 (p. 257) [versão brasileira: "Os Estados no(s) centro(s) e os Estados na(s) periferia(s): alguns problemas com a concepção de Estados da sociedade mundial em Niklas Luhmann". Revista de Informação Legislativa, 52/206, 20I5, p. III-I36 (p. I2I): "efetivação suficiente" em vez de "adäquate Realisierung" da ed. alemã]. Na sua citação Mascareño retira as expressões "realização da" ["Realisierung der"] e "sistêmica" ["System-"] do meu original. Para a ideia da "diferenciação funcional plenamente desenvolvida" como caraterística da sociedade moderna (mundial), cf., por exemplo, Luhmann, Niklas. Das Recht der Gesellschaft, p. I92.

30 Cf. também Neves, Marcelo. "Posfácio à edição brasileira (20I8): Constitucionalismo periférico 26 anos depois", p. 368-378.

3I Dantas, Maria Eduarda. Constitucionalismo periférico e teoria dos sistemas sociais: por uma interpretação pós-colonial da tese da constitucionalização simbólica. Dissertação de Mestrado em ciência política. IPOL/Universidade de Brasília.

32 Chatterjee, Partha. The politics of the governed. Reflections on popular politics in most of the world. New York: Columbia University Press, 2004. 
33 Holmes, Pablo. "A sociedade civil contra a população: uma teoria crítica dos constitucionalismos brasileiros de I988" (inédito); Holmes, Pablo \& Dantas, Maria Eduarda. "A sociedade mundial desde a periferia: Sociologia constitucional em Marcelo Neves" (inédito).

34 Luhmann, "Zur Einführung", p. 3 [trad. bras.: "Prefácio à edição alemã”, p. XXI].

35 Stichweh, Rudolf. "Evolutionary theory and the theory of worldsSociety". Soziale Systeme I3, 2007, p. 528-542, espec. p. 528-529.

36 Luhmann, Niklas. Das Recht der Gesellschaft, p. 579-580.

37 Luhmann, Niklas. Das Recht der Gesellschaft, p. 8I-82.

38 Luhmann, Niklas. Die Gesellschaft der Gesellschaft, tomo 2, p. I043.

39 Neves, Marcelo. Transconstitucionalismo, p. 45.

40 Neves, Marcelo. Verfassung und Positivität des Rechts in der peripheren Moderne, p. 78-79, 94ss. [trad. bras.: Constituição e direito na modernidade periférica, p. I09-I10, I32ss.]; "Entre subintegração e sobreintegração: a cidadania inexistente". Dados - Revista de Ciências Sociais, 37/2, I994, p. 253-276.

4I Cf. as seguintes reportagens: <https://www.bbc.com/ sport/football/43265299>; <https://www.uol.com.br/esporte/futebol/ultimas-noticias/2018/03/05/presidente-do burundi-se-irrita-em-jogo-de-futebol-e-prende-adversarios.htm>;<https://www.espn.com.br/futebol/artigo/_/ $\mathrm{id} / 405$ I899/presidente-de-pais-organiza-pelada-e-dois jogadores-rivais-acabam-na-cadeia-por-marcarem-politico-de-verdade>; <https://www.thesun.co.uk/sport/football /5 717008/burundi-officials-jailed-after-presidentroughed-up-in-game/>; <https://face2faceafrica.com/article/two-buru ndi-officials-arrested-president-nkurunziza-roughed-game>, acesso em 26 jan. 2020.

42 Sommer, Theo. "Die verlorene Ehre des Uwe Barschel”. Die Zeit Online, 4 dez. I987. Disponível em: <https://www.zeit. de/I987/50/die-verlorene-ehre-des-uwe-barschel/komplettansicht>, acesso em 24 jan. 2020.

43 Distinção que remete a Marx, Karl. Das Elend der Philosophie. Antwort auf Proudhons Philosophie des Elends [1847]. In: MaxEngels-Werke (MEW), v. 4. 5 ed. Berlin: Dietz Verlag, I977, p. 63-I82 (p. I80-I8I) [original francês: Misère de la philo- 
sophie. Réponse à la Philosophie de la misère de Proudhon. Paris: A. Franck, I847; 3 ed. Paris: V. Giard/E. Brière, I896, p. 242]. Advirta-se que, em Marx, não consta explicitamente a expressão classe em si [Klasse an sich], mas apenas a expressão classe para si mesma [classe pour ele-même, Klasse für sich selbst].

44 Marx, Karl. Der achtzehnte Brumaire des Louis Bonaparte [1852]. In: Marx-Engels-Werke (MEW), v.8. Berlin: Dietz Verlag, I96o, p. I I I-207, passim; Das Kapital. Kritik der politischen Ökonomie, v. I [1867]. In: Marx-Engels-Werke (MEW), v. 23. Berlin: Dietz Verlag, I962, espec. p. 657 ss.; Marx, Karl \& Engels; Friedrich. Die deutsche Ideologie: Kritik der neuesten deutschen Philosophie in ihren Repräsentanten Feuerbach, B. Bauer und Stirner [I845-I846]. In: Marx-Engels-Werke (MEW). v. 3.5 ed. Berlin: Dietz Verlag, I978, p. 8-530, passim; Manifest der Kommunistischen Partei. In: Marx-Engels -Werke (MEW), v. 4.5 ed. Berlin: Dietz Verlag, I977, p. 459-493, espec. p. 472.

45 Luhmann, Niklas. Rechtssystem und Rechtsdogmatik. Stuttgart: Kohlhammer, I974, p. 7I.

\section{REFERÊNCIAS BIBLIOGRÁFICAS}

Elder-Vass, Dave. (2007). Luhmann and emergentism: competing paradigms for social systems theory?. Philosophy of the Social Sciences, 37/4, p. 408-432.

Leydesdorff, Loet. (200I). The challenge of scientometrics: the development, measurement, and self-organization of scientific communications. [sl]: Universal-Publishers.

Luhmann, Niklas. (I986). The theory of social systems and its epistemology: reply to Danilo Zolo's critical comments. Philosophy of the Social Sciences, I6/I, p. I29-I34.

Luhmann, Niklas. (1984). Soziale Systeme. Frankfurt: Suhrkamp.

Luhmann, Niklas. (1983). Insistence on systems theory. Social Forces, 6I/4, p. 987-998.

Moretti, Franco. (2013). Distant reading. London/New York: Verso Books. 


\section{O CENÁRIO “PÓS-LUHMANNIANO" E A AMÉRICA LATINA: ENTREVISTAS COM MARCELO NEVES E ALDO MASCAREÑO}

Resumo

Em finais de 20I9, entrevistamos por e-mail os professores Marcelo Neves e Aldo Mascareño, sugerindo-lhes um eixo comum de perguntas sobre suas trajetórias e sobre os principais desafios envolvidos na tarefa de aclimatar a teoria dos sistemas sociais de Niklas Luhmann ao contexto latino-americano. Além das duas entrevistas, fizemos uma sucinta apresentação do que denominamos cenário "pós-luhmanniano" e do potencial da recepção latino-americana para a renovação do legado sistêmico no presente, incluindo breve exploração bibliométrica de alguns padrões dessa recepção.

\section{THE 'POST-LUHMANNIAN' SCENARIO AND LATIN AMERICA: INTERVIEWS WITH MARCELO NEVES AND ALDO MASCAREÑO}

Abstract

At the end of 20I9, we interviewed by email Professors Marcelo Neves and Aldo Mascareño, presenting them with a similar list of questions on their intellectual trajectories and the principal challenges involved in the task of adapting Niklas Luhmann's social systems theory to the Latin American context. As well as the two interviews, we provide a brief presentation of what we call the 'post-Luhmannian' scenario and the potential for its Latin American reception to renew the systemic legacy in the present, including a short bibliometric exploration of some of the patterns evident in this reception.

\section{Palavras-chave}

Niklas Luhmann;

Marcelo Neves;

Aldo Mascareño;

América Latina;

teoria dos sistemas.

\section{Keywords}

Niklas Luhmann;

Marcelo Neves;

Aldo Mascareño;

Latin America;

systems theory. 